\title{
ARTICLES \\ MISALIGNMENT: CORPORATE RISK-TAKING AND PUBLIC DUTY
}

\author{
Steven L. Schwarcz*
}

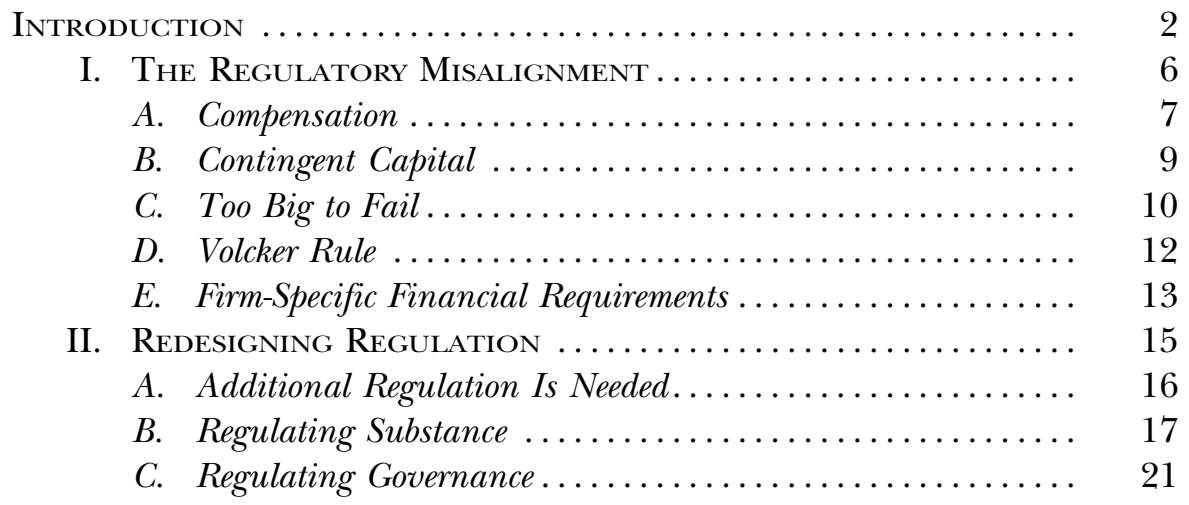

III. Towards Regulatory Alignment: A Public Governance

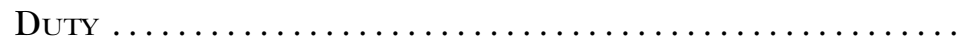

(C) 2016 Steven L. Schwarcz. Individuals and nonprofit institutions may reproduce and distribute copies of this Article in any format at or below cost, for educational purposes, so long as each copy identifies the author, provides a citation to the Notre Dame Law Review, and includes this provision in the copyright notice.

* Stanley A. Star Professor of Law \& Business, Duke University School of Law; Founding Director, Duke Global Financial Markets Center; Senior Fellow, the Centre for International Governance Innovation. E-mail: schwarcz@law.duke.edu. For valuable comments, I thank Emilios Avgouleas, John de Figueiredo, Deborah DeMott, Lisa M. Fairfax, Jesse D. Gossett, Matthias Haentjens, John Hasnas, Edward Kane, Ian B. Lee, Robert T. Miller, Marc T. Moore, Peter O. Muelbert, Zhong Xing Tan, Gabe Shawn Varges, Charles Whitehead, and participants in the 2015 Distinguished Public Lecture in Corporate Governance at the University of Florence, in the 2016 Financial Regulation Roundtable at Columbia University, and in faculty workshops at the University of Iowa College of Law, the University of Zurich Institute of Law (co-sponsored by the University of Zurich Centre for Financial Regulation), and (jointly via virtual connection) Duke University School of Law and Shanghai University of International Business and Economics (SUIBE) School of Law. I also thank Brittany LaFleur, Tashi Sun, and Ruiyao Sun for invaluable research assistance. Support is provided in part by a Fuller-Purdue grant. 
A. Analyzing a Public Governance Duty Under Corporate

Governance Legal Theory ...................... 23

1. The Stakeholder Model of Governance ......... 24

2. The Contractarian Model of Governance ........ 26

3. The Shareholder-Primacy Model ............. 27

B. Implementing a Public Governance Duty............ 28

1. Legally Imposing the Duty ............... 29

2. Assessing Costs and Benefits ............... 32

3. Balancing Costs and Benefits ............. 35

4. Enforcing a Public Governance Duty ......... 37

5. Business Judgment Rule as a Defense.......... 39

6. Protecting Managers Under D\&O Liability Insurance ........................... 43

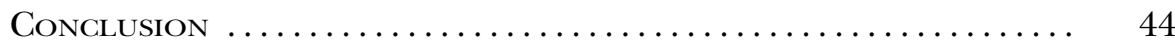

Appendix: Model Regulatory Language for a Public

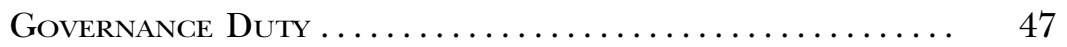

Public Governance Duty Act ...................... 47

SECTION 1. TITLE ...................... 47

SECTION 2. DEFINITIONS .............. 47

SECTION 3. PUBLIC GOVERNANCE DUTY ...... 47

SECTION 4. LIABILITY AND ENFORCEMENT ... 48

SECTION 5. DEFENSES AND INSURANCE ...... 49

SECTION 6. WHISTLEBLOWING RIGHTS AND

OBLIGATIONS ........................ 49

\section{Abstract}

This Article argues for a "public governance duty" to help manage excessive risk-taking by systemically important firms. Although governments worldwide, including the United States, have issued an array of regulations to attempt to curb that risk-taking by aligning managerial and investor interests, those regulations implicitly assume that investors would oppose excessively risky business ventures. That leaves a critical misalignment: because much of the harm from a systemically important firm's failure would be externalized onto the public, including ordinary citizens impacted by an economic collapse, such a firm can engage in risk-taking ventures with positive expected value to its investors but negative expected value to the public. The Article analyzes why corporate governance law should, and shows how it feasibly could, take the public interest into account.

\section{INTRODUCTION}

Should corporate governance law take into account risk-taking that could systemically harm the public? Corporate risk-taking is certainly economically necessary and often desirable. ${ }^{1}$ Successful risk-taking increases

1 Cf. Gabriel Jiménez et al., How Does Competition Impact Bank Risk-Taking? (Fed. Reserve Bank of S.F. Working Paper Series No. 2007-23, 2007), http://www.frbsf.org/eco- 
profitability, thereby enhancing welfare by generating jobs and purchasing power. ${ }^{2}$ But corporate risk-taking can sometimes cause harm. There is widespread agreement that excessive corporate risk-taking was one of the primary causes of the systemic economic collapse that became the 2008-2009 global financial crisis (the "financial crisis"). ${ }^{3}$ There is also a consensus that existing regulatory measures to curb that risk-taking and prevent another crisis are inadequate. ${ }^{4}$

Many of the regulatory responses to the financial crisis, both in the United States and abroad, seek to mitigate excessive risk-taking by systemically important financial firms. ${ }^{5}$ Various of those responses are designed to control that risk-taking by aligning managerial and investor interests to reduce agency costs and make managers less likely to engage their firms in risky business ventures that could jeopardize investors. These responses

nomic-research/publications/working-papers/2007/wp07-23bk.pdf (arguing that increasing competition among banks increases the need to engage in risk-taking in order to maintain profitability).

2 See, e.g., David Rosenberg, Supplying the Adverb: The Future of Corporate Risk-Taking and the Business Judgment Rule, 6 Berkeley Bus. L.J. 216, 221-22 (2009) (observing that students of American law and economic history agree that much of the nation's technological progress and economic growth can be partly attributed to bold corporate risk-taking).

3 See, e.g., Fin. Crisis Inquiry Comm'n, The Financial Crisis Inquiry Report: Final Report of the National Commission on the Causes of the Financial and Economic CRISIS IN THE UNITED STATES, xviii-xix (2011), http://fcic-static.law.stanford.edu/cdn_ media/fcic-reports/fcic_final_report_full.pdf (identifying excessive risk-taking as a primary cause of the financial crisis); Jacob J. Lew, Opinion, Let's Leave Wall Street's Risky Practices in the Past, Wash. Post (Jan. 9, 2015), https://www.washingtonpost.com/opinions/jacob-lewlets-leave-wall-streets-risky-practices-in-the-past/2015/01/09/cf25b5f6-95d8-11e4-aabd-d0b9 3ff613d5_story.html?utm_term=.d1eddb5d0774 (explaining that U.S. Treasury Secretary Lew repeatedly attributes the financial crisis to "excessive risks taken by financial" firms); The Origins of the Financial Crisis: Crash Course, Economist (Sept. 7, 2013), http://www.eco nomist.com/news/schoolsbrief/21584534-effects-financial-crisis-are-still-being-felt-fiveyears-article (identifying excessive risk-taking as one of three causes of the financial crisis, the other causes being irresponsible lending and regulators being asleep at the wheels).

4 See, e.g., Binyamin Appelbaum, Skepticism Prevails on Preventing Crisis, N.Y. TIMes, Oct. 5, 2015, at B1 (observing the "troubling reality highlighted at a conference . . a the Federal Reserve Bank of Boston" that "policy makers have made little progress in figuring out how they might actually" prevent another financial crisis). Donald Kohn, former Vice Chairman of the United States Federal Reserve Board, observed at the conference that the Federal Reserve "doesn't really have the tools" to prevent another crisis. Id. at B3. Luc Laeven, European Central Bank Director General for Research, summarized the consensus reached at the conference: "Both monetary policy and macroprudential [regulatory] policy are not really very effective." Id. He then asked, "Do we have other policies?" Id. This Article seeks to provide an answer.

5 Cf. infra Part I (discussing regulatory responses to mitigate excessive corporate risktaking by systemically important firms). This Article's references to systemically important firms, systemically important financial firms, and systemically important financial institutions all mean financial firms that are systemically important. Very large and highly interconnected non-financial firms that might be systemically important are beyond the Article's scope. 
implicitly assume that the investors themselves would oppose excessively risky business ventures.

That assumption, however, is flawed, and therefore financial regulation based on the assumption's validity is unreliable. The assumption is flawed because what constitutes "excessive" risk-taking depends on the observer. Risk-taking is excessive from a given observer's standpoint if it has a negative expected value to that observer (i.e., the expected costs to that observer exceed the expected benefits). Thus, it is reasonable to assume that investors would oppose risky business ventures that have a negative expected value to them. The problem, however, is that systemically important firms-the primary focus of post-financial crisis regulation, and also the focus of this Article-can engage in risk-taking ventures that have a positive expected value to their investors but a negative expected value to the public. That is because much of the systemic harm from such a firm's failure would be externalized ${ }^{6}$ onto other market participants as well as onto the public, including ordinary citizens impacted by an economic collapse. ${ }^{7}$

This misalignment occurs because corporate governance law requires managers of a firm-by which this Article means the most senior managers who have ultimate responsibility to manage the firm, such as a corporation's directors - to view the consequences of their firm's actions, and thus to view the expected value of corporate risk-taking, only from the standpoint of the firm and its investors. ${ }^{8}$ That perspective ignores externalities ${ }^{9}$ caused by the

6 This could be described as a type of "tragedy of the commons," insofar as market participants suffer from the actions of other market participants. But it also is a more standard externality insofar as non-market participants (i.e., the ordinary citizens impacted by an economic collapse) suffer from the actions of market participants; $c f$. Sean J. Griffith, Governing Systemic Risk: Towards a Governance Structure for Derivatives Clearinghouses, 61 EMORY L.J. 1153, 1156, 1210 (2012) (describing a similar misalignment as a free-rider and moral hazard problem).

7 Steven L. Schwarcz, Systemic Risk, 97 GEO. L.J. 193, 206 (2008); see also John Crawford, The Moral Hazard Paradox of Financial Safety Nets, 25 Cornell J.L. \& Pub. Pol'y 95, 138 (2015) (observing that "financial firms . . . are under-incentivized to insure at the optimal level, given the fact that the potential systemic costs of their own failure would be borne primarily by others"). The collapse of Lehman Brothers illustrates this. Lehman Brothers had engaged in highly profitable, but also high-risk and high-leverage, business strategies. The financial stresses caused by "defaults in the subprime mortgage and commercial real estate markets" then caused Lehman Brothers to default, roiling financial markets and threatening the entire U.S. economy with collapse. Edward J. Estrada, The Immediate and Lasting Impacts of the 2008 Economic Collapse-Lehman Brothers, General Motors, and the Secured Credit Markets, 45 U. Rich. L. Rev. 1111, 1115-18 (2011).

8 See, e.g., Richard A. Brealey et al., Principles of Corporate Finance 9-10 (10th ed. 2011); cf. Bd. of Governors of the Fed. Reserve Sys., Calibrating the GSiB Surcharge 1 (2015) [hereinafter Board of Governors of the Federal Reserve System], https://www.federalreserve.gov/aboutthefed/boardmeetings/gsib-methodology-paper20150720.pdf (observing that systemically important financial institutions "themselves lack sufficient incentives to take precautions against their own failures"). In some jurisdictions, however, managers may also be allowed or required to take into account other interests, such as those of employees, suppliers, customers, creditors, and communities, see infra note 
actions. In general, that makes sense because myriad externalities result from corporate risk-taking; ${ }^{10}$ it would not be feasible to take all those externalities into account. Even the Federal Reserve's regulations requiring systemically important financial firms to establish risk committees direct those committees to consider risks to the firm, not to the public. ${ }^{11}$ But risk-taking that causes the failure of a systemically important firm could trigger a domino-like collapse of other firms or markets, causing systemic externalities that damage the economy and harm the public. ${ }^{12}$ This Article argues that corporate governance law should, and feasibly could, take into account risk-taking that causes systemic externalities.

The Article proceeds as follows. Part I examines the "macroprudential" regulatory responses to the financial crisis-that is, regulatory responses intended to protect against "systemic" risk to the integrity of the financial system ${ }^{13}$ - that purport to mitigate excessive corporate risk-taking by systemically important firms. ${ }^{14}$ To the extent these responses attempt to mitigate that risk-taking by aligning interests, they seek to align managerial and investor interests (collectively, the "firm's interests"). That leaves a critical misalignment: even if those interests could be perfectly aligned, that would be insufficient to control excessive risk-taking that causes systemic externalities. Part I also shows that the regulatory responses to the financial crisis that profess to mitigate excessive corporate risk-taking in other ways (i.e., without aligning managerial and investor interests) are also inadequate to prevent systemic externalities.

Part II examines and compares possible regulatory redesign options to help align the firm's interests with the public's interests, in order to control excessive risk-taking that causes systemic externalities. Although financial regulation traditionally focuses on regulating substance, such as imposing capital-adequacy standards, this Part argues that these redesign options should additionally focus on reforming a firm's governance.

Part III analyzes how a firm's governance should be reformed to reduce systemic externalities. To that end, it first shows how imposing a public governance duty to help align the firm's interests with the public's interests would fit within corporate governance legal theory. Thereafter, it shows how such a duty could be feasibly and efficiently implemented. Finally, the

160 and accompanying text (discussing the Pennsylvania constituency statute), and "the entire national economy," see infra note 158 (discussing legislation in Iceland).

9 I am talking, of course, about non-investor externalities; cf. Griffith, supra note 6, at 1210 (in the context of derivatives transactions, observing that "[b] ecause no private party can enjoy the full benefit of eliminating systemic risk, no private party has an incentive to fully internalize the cost of doing so").

10 See infra notes 84-85 and accompanying text.

11 See infra notes 168-70 and accompanying text.

12 Schwarcz, supra note 7, at 198.

13 Id. (defining systemic risk).

14 Cf. supra text accompanying notes 5-13; infra notes 15-68 (discussing why such risktaking occurs). 
Appendix to the Article proposes possible model language, in the form of a Public Governance Duty Act, for regulation imposing the duty.

\section{The Regulatory Misalignment}

Various types of macroprudential regulatory responses to the financial crisis purport to mitigate excessive corporate risk-taking by systemically important firms. ${ }^{15}$ Certain of these responses attempt to mitigate that risktaking by aligning managerial and investor interests. Thus, requiring a systemically important firm to tie management compensation to the firm's longterm performance is intended to better align managerial and investor interests by penalizing managers who engage such firms in risky ventures that, notwithstanding short-term appeal, ultimately jeopardize investors. ${ }^{16}$ Requiring a systemically important firm to maintain so-called contingent capital, in which debt securities convert into equity securities upon specified conditions, is designed to motivate holders of those convertible debt securities to better monitor and impose covenants against excessive risk-taking, since they more clearly bear the risk of the firm failing. ${ }^{17}$ As shown below, however, these types of responses are insufficient: even if managerial and investor interests to engage in risk-taking could be perfectly aligned, that would be insufficient to control risk-taking that causes systemic externalities.

Other types of regulatory responses that are currently used to control excessive corporate risk-taking by systemically important firms do not profess to align managerial and investor interests. Because there is no formal categorization of macroprudential regulatory responses, ${ }^{18}$ there is no formal categorization of this subset of responses. For discussion purposes, this Article

15 Recall that macroprudential regulation focuses on the integrity of the financial system, as a system, in contrast to microprudential regulation, which focuses on the safety and soundness of individual firms. See supra note 13 and accompanying text. These forms of regulation have an indirect overlap: reducing the likelihood that individual firms will fail can help to partially reduce systemic risk by making it less likely that individual systemically important firms will fail. Microprudential regulation does not, however, generally address correlations among failing firms, nor does it address how to protect the financial system as a system. Rizwaan Jameel Mokal argues that trying to make the financial system stable by making it less likely that individual systemically important firms will fail can actually increase financial instability. Rizwaan Jameel Mokal, Liquidity, Systemic Risk, and the Bankruptcy Treatment of Financial Contracts, 10 Brook. J. Corp. Fin. \& Com. L. 15, 20 (2015).

16 See infra Section I.A.

17 See infra Section I.B. These convertible debt securities are sometimes called contingent convertible securities, or "CoCos." See, e.g., John Glover \& Tom Beardsworth, Contingent Convertibles, BloOmberG VIEw (July 29, 2016), http://www.bloombergview.com/ quicktake/contingent-convertible-bonds.

18 Policymakers and regulators tend to view macroprudential regulation as a loose assortment of "tools" in their toolkit. See, e.g., Robert Hockett, Implementing Macroprudential Finance-Oversight Policy: Legal Considerations 12-13 (Jan. 20, 2013) (unpublished manuscript) (on file with author) (discussing the "emergent macroprudential toolkit as currently constituted"). Even the theoretical scholarship on macroprudential regulation takes a somewhat similar ad hoc approach, yielding "propositions [that] can serve as a tool kit" for regulatory scrutiny. Daniel Awrey, Colleen Baker \& Katharina Pistor, 
categorizes these responses along functional lines: regulation attempting to limit the so-called too-big-to-fail (TBTF) problem, ${ }^{19}$ regulation implementing the so-called Volcker Rule, ${ }^{20}$ and regulation imposing capital and other types of firm-specific financial requirements. ${ }^{21}$ Some of these categories overlap. ${ }^{22}$ However one categorizes these responses, however, the analysis below shows-and policymakers agree ${ }^{23}$ - that they too are inadequate to control risk-taking that causes systemic externalities.

\section{A. Compensation}

One approach to control excessive corporate risk-taking is to better align managerial compensation with investor interests. To this end, commentators, legislators, and regulators have proposed aligning the long-term compensation of senior and secondary managers of systemically important firms with the interests of those firms' investors. ${ }^{24}$ The U.S. Securities and Exchange Commission (SEC), for example, is authorized to enforce the recovery of bonuses paid to chief executive officers and chief financial officers of public companies that issue financial restatements due to material noncompliance "with any financial reporting requirement under the securities laws" resulting from misconduct. ${ }^{25}$ The SEC also requires all firms whose compensation policies create risks that are "reasonably likely to have a material adverse effect" on the firm to disclose, in the form of a "narrative discourse," how those compensation policies relate to risk management and risk-taking incentives. ${ }^{26}$

An Overview of the Legal Theory of Finance 2 (2014) (unpublished manuscript) (on file with author).

19 See infra Section I.C.

20 See infra Section I.D.

21 See infra Section I.E.

22 For example, regulation imposing capital and other types of firm-specific financial requirements can overlap with TBTF regulation because both can make it less likely that a TBTF firm will fail.

23 See Appelbaum, supra note 4.

24 For a comparison of senior and secondary manager compensation, including an argument that the latter is at least as important as the former, see Steven L. Schwarcz, Conflicts and Financial Collapse: The Problem of Secondary-Management Agency Costs, 26 YALE J. ON REG. 457 (2009).

25 See Dodd-Frank Wall Street Reform and Consumer Protection Act, Pub. L. No. 111203, §§ 951-56, 971, 972, 124 Stat. 1376, 1899-906, 1915 (2010) (codified at 15 U.S.C. $\S 78 n-1$ (2012)) (adding $\S \S 14 A, 10 \mathrm{C}, 14(\mathrm{i}), 10 \mathrm{D}, 14(\mathrm{j}), 14(\mathrm{a})(1)$, and 14B to the Securities Exchange Act of 1934, Pub. L. No. 111-203, 124 Stat. 1899, which extended the federal government's regulatory reach into a company's internal governance and compensation practices even further); Sarbanes-Oxley Act of 2002, Pub. L. No. 107-204, § 304, 116 Stat. 745, 778 (2002) (codified at 15 U.S.C. $\$ 7243$ (2012)).

26 Lisa M. Fairfax, Government Governance and the Need to Reconcile Government Regulation with Board Fiduciary Duties, 95 Minn. L. Rev. 1692, 1704 (2011) (quoting Proxy Disclosure Enhancements, 74 Fed. Reg. 68,334 (Dec. 23, 2009) (codified at 17 C.F.R. pts. 229, 239, $240,249,274))$ 
Even greater restrictions were placed on firms receiving bailout moneys in connection with the financial crisis. For example, these firms had ceilings imposed on the compensation payable to the five highest-earning executives, in order to eliminate incentives to take "unnecessary and excessive risks that threaten the value of such" a firm. ${ }^{27}$ These firms also were required to have an independent "Board Compensation Committee," which would meet "to discuss and evaluate employee compensation plans in light of an assessment of any risk posed to [such a firm] from such plans." 28 Additionally, they were required to recover any form of incentive compensation paid to a senior executive officer and any of the next 20 most highly-compensated employees" if the financial statements or other criteria on which the compensation was based later is found to be "materially inaccurate." 29 The Dodd-Frank Act extends certain of these requirements to firms that are required to file periodic reports to the SEC. ${ }^{30}$ It also requires firms to implement shareholder advisory voting on executive compensation, commonly known as "say-onpay."31

Nonetheless, a misalignment remains because these compensation requirements focus exclusively on the effect of risk-taking on the firm and its investors. None of these requirements takes into account the potential for risk-taking to create systemic externalities. ${ }^{32}$ These requirements therefore will be insufficient to control that risk-taking. ${ }^{33}$

27 American Recovery and Reinvestment Act of 2009, Pub. L. No. 111-5, 123 Stat. 115, 517 (adding $§ 111$ (b) (3) (A) to the Emergency Economic Stabilization Act of 2008, Pub. L. 110-343, 122 Stat. 3765 (codified as amended in scattered sections of 12 U.S.C. (2012))); see also id. (amending $\$ 111$ of the Emergency Economic Stabilization Act of 2008 to include §111(b) (3) (A)) (preventing the executives with the top five highest salaries of any TARP company from receiving compensation incentivizing them to take "unnecessary and excessive risks that threaten the value" of the firm).

28 American Recovery and Reinvestment Act $\$ 7001$ (adding $§ 111$ (b) (4) to the Emergency Economic Stabilization Act).

29 Id. (adding \$ 111(b) (3) (B) to the Emergency Economic Stabilization Act).

30 See, e.g., Dodd-Frank Act $\$ 954$ (requiring senior managers to return any compensation they received in the past three years based on erroneous financial reports submitted to the SEC).

31 Id. § 951; Press Release, U.S. Sec. \& Exch. Comm'n, SEC Adopts Rules for Say-onPay and Golden Parachute Compensation as Required Under Dodd-Frank Act (Jan. 25, 2011), https://www.sec.gov/news/press/2011/2011-25.htm.

32 Cf. Peter F. Drucker, The New Society: The Anatomy of Industrial Order 340-43 (1950) (arguing that board alignment with shareholder interests would weaken the desirable capacity of managers to manage in the public interest); Jesse D. Gossett, Note, Financial Institution Executive Compensation: The Problem of Financially Motivated Excessive RiskTaking, the Regulatory Response, and Common Sense Solutions, 14 U.C. Davis Bus. L.J. 51, 63 (2013) (observing that the compensation provisions of the Dodd-Frank Act and the Sarbanes-Oxley Act "will do nothing to actually reduce the level of systemic risk at financial institutions which means [such provisions] will be largely ineffective at holding off the next financial crisis").

33 Professors Bebchuk and Spamann have partly recognized that insufficiency, arguing that compensation of a bank's "top executives" should be tied not only to common stock value but also to preferred share and bond value in order to better protect the government 


\section{B. Contingent Capital}

Contingent capital regulation assumes that a firm's creditors-who would not benefit from the firm's increased profitability but could be harmed by its failure-should be good monitors against excessive risk-taking if they more clearly bear the risk of the firm failing. To assign more of that risk to creditors, such regulation requires certain debt claims to convert to equity upon specified (deteriorating) financial conditions. ${ }^{34}$ To reduce the chance those conditions will occur, creditors impose even stricter loan covenants on their debtor-firms. ${ }^{35}$ That aligns managerial and investor interests by contractually restricting risk-taking.

Contingent capital regulation is unlikely to be sufficient to control risktaking that causes systemic externalities. Admittedly, it might indirectly and partially reduce systemic risk by reducing the likelihood that any given firm will fail. ${ }^{36}$ As a practical matter, however, the firm and its shareholders will want the firm to be able to engage in risk-taking in order to make profits. ${ }^{37}$ Firms customarily offer creditors higher interest rates to compensate for allowing looser covenants, ${ }^{38}$ and experience shows that creditors often "go for the gold," choosing the higher rates over stronger covenants. ${ }^{39}$ If private and public interests were perfectly aligned, the pricing theoretically should offset the risks. But in negotiating loan covenants, creditors have no incen-

as a guarantor of bank deposits. Lucian A. Bebchuk \& Holger Spamann, Regulating Bankers' Pay, 98 Geo. L.J. 247, 254 (2010). In that context, they examine "corporate governance measures aiming to align management with shareholders" and conclude, as do I, that such measures will not fix the insufficiency and might even make it worse. Id. at 274-75. Unlike my Article, however, they do not consider how corporate governance measures might be reformed to help align management with societal interests.

34 Debt securities that are required to convert to equity securities upon certain conditions, such as the debtor-firm's equity capital falling below a pre-set minimum, are often called contingent convertible securities or, more simply, "CoCos." See supra note 17. Contingent capital regulation also serves to convert debt claims of a troubled firm into equity interests, thereby reducing the likelihood that the firm will default. See infra note 62.

35 Cf. Simone M. Sepe, Corporate Agency Problems and Dequity Contracts, 36 J. Corp. L. 113, 127 (2010) (footnote omitted) (observing that "although the law grants creditors no special rights against managers, creditors can acquire substantial control powers over corporate operations by bargaining for both positive and negative covenants").

36 See supra note 15.

37 As discussed, corporate risk-taking is economically necessary and desirable. See supra note 2 and accompanying text. But cf. John Armour \& Jeffrey N. Gordon, Systemic Harms and Shareholder Value, 6 J. Legal ANAlysis 35, 54 (2014) (arguing that because systemic risks cannot be avoided by investment diversification, shareholders can be indirectly harmed by excessive risk-taking that triggers a systemic collapse).

38 See, e.g., Steven L. Schwarcz, Rethinking a Corporation's Obligations to Creditors, 17 CARDozo L. Rev. 647, 651 n.12 (1996).

39 Larry Light, Bondholder Beware: Value Subject to Change Without Notice, BloomberG (Mar. 29, 1993), http://www.bloomberg.com/bw/stories/1993-03-28/bondholder-bewarevalue-subject-to-change-without-notice ("Bondholders can-and will-fuss all they like. But the reality is, their options are limited: Higher returns or better protection [in the form of stronger covenants]. Most investors will continue to go for the gold.”). 
tive to control systemic externalities. They therefore will not price in the systemic consequences of risk-taking. ${ }^{40}$

Also, contingent capital regulation could have unintended consequences. Because it is riskier, debt issued as contingent capital would be more expensive than non-convertible debt. ${ }^{41}$ Capitalizing a systemically important firm with lots of contingent capital, in order to make the firm less likely to fail, might also motivate the firm's managers to take even greater corporate risks. ${ }^{42}$

The foregoing discussion has focused on controlling excessive corporate risk-taking by aligning managerial and investor interests, showing that existing regulatory responses are insufficient to prevent systemic externalities. This Article next examines whether regulatory responses that profess to control excessive corporate risk-taking in other ways could prevent systemic externalities.

\section{Too Big to Fail}

Another type of regulatory response to control excessive corporate risktaking focuses on the "Too Big to Fail" problem: that systemically important firms might engage in excessive risk-taking because they would profit by a success and be bailed out by the government in case of a failure. This is a problem of moral hazard, that persons protected from the negative consequences of their risky actions will be more tempted to take risks. ${ }^{43}$

TBTF regulation seeks to reduce that moral hazard by limiting the government's authority to provide bailouts. In the United States, for example, it restricts the Federal Reserve's authority to act as a lender of last resort to a failing financial institution. ${ }^{44}$

40 Nor are creditor-imposed loan covenants likely to protect the financial system, as a system. Cf. Iman Anabtawi \& Steven L. Schwarcz, Regulating Ex Post: How Law Can Address the Inevitability of Financial Failure, 92 TEx. L. REv. 75, 87 (2013) (examining how macroprudential regulation should help to protect the financial system, as a system).

41 See, e.g., Eric S. Halperin, CoCo Rising: Can the Emergence of Novel Hybrid Securities Protect from Future Liquidity Crises?, 8 InT'L L. \& MGMt. Rev. 15, 21-24 (2011) (explaining why issuing CoCos to investors may be more expensive than issuing ordinary debt).

42 Cf. George Pennacchi, A Structural Model of Contingent Bank Capital 30 (Fed. Reserve Bank of Cleveland, Working Paper No. 10-04, 2011), https://business.illinois.edu/gpennacc/ConCap030211.pdf (observing that a "bank that issues contingent capital faces a moral hazard incentive to increase its assets' jump risks”). Another possible unintended consequence of contingent capital is that "by requiring banks to issue more debt, it might prompt some to reduce their ratios of equity to assets. This added leverage will leave the system more susceptible to distress in bad times." Editorial, A Bad Way to Make Banks Safe, Bloomberg View (Nov. 9, 2015), https://www.bloomberg.com/view/articles/2015-11-09/ a-bad-way-to-make-banks-safe.

43 See, e.g., Gary H. Stern \& Ron J. Feldman, Too Big to Fail: The Hazards of Bank BaIlouts (2004).

44 The Dodd-Frank Act limits the authority of the Federal Reserve to make emergency loans under $\S 13(3)$ of the Federal Reserve Act. Dodd-Frank Wall Street Reform and Consumer Protection Act, Pub. L. No. 111-203, § 1101(a) (6), 124 Stat. 2113, (2010) (codified 
This aspect of TBTF regulation is unlikely to be sufficient to control excessive risk-taking, and it might even increase systemic externalities. It is unlikely to be sufficient to control excessive risk-taking because the misalignment discussed in this Article results from externalized harm, not from reliance on a bailout. ${ }^{45}$ And it might inadvertently increase systemic externalities by preventing the government from bailing out a failing systemically important firm. ${ }^{46}$

TBTF regulation also focuses on making systemically important firms less likely to need a government bailout if they suffer devastating losseswhether or not those losses are caused by excessive risk-taking. ${ }^{47}$ The DoddFrank Act, for example, requires systemically important firms to file so-called living wills, setting forth how they could liquidate with minimal systemic impact. $^{48}$ Because this focus of TBTF regulation does not purport to control excessive corporate risk-taking, it is not central to this Article's analysis. ${ }^{49}$

at 12 U.S.C. $§ 343$ (2012)). Dodd-Frank amended that subsection to require the Federal Reserve to consult with and receive approval from the Secretary of the Treasury to ensure that any emergency lending is designed to provide liquidity to the markets and not to aid a financially failing firm. $I d$.

45 See supra notes 7-12 and accompanying text.

46 See, e.g., Iman Anabtawi \& Steven L. Schwarcz, Regulating Systemic Risk: Towards an Analytical Framework, 86 Notre Dame L. Rev. 1349, 1376 (2011); John C. Coffee, Jr., Systemic Risk After Dodd-Frank: Contingent Capital and the Need for Regulatory Strategies Beyond Oversight, 111 Colum. L. Rev. 795, 825 (2011) (observing that the Dodd-Frank Act prevents federal government lender-of-last-resort assistance to nonbank financial firms that are solvent but illiquid, thereby forcing "some firms into an arguably unnecessary liquidation").

47 Yet another focus of TBTF regulation is on reducing the TBTF nature of systemically important firms, such as Senator Elizabeth Warren's proposal to break up large banks. See Joseph Lawler, Warren Introduces Glass-Steagall Bill to Break Up Big Banks, WASH. ExAmINER (July 7, 2015), http://www.washingtonexaminer.com/warren-introduces-glass-steagall-billto-break-up-big-banks/article/2567757.

48 See, e.g., Jennifer Meyerowitz \& Joseph N. Wharton, A Dodd-Frank Living Wills Primer: What You Need to Know Now, 31 Am. BAnkr. Inst. J. 34, 34 (2012) ("As part of the goal to remove the risks to the financial system posed by 'too big to fail' institutions, $\$ 165$ (d) of the Dodd-Frank Act requires 'systemically important financial institutions' to create 'living wills' to facilitate 'rapid and orderly resolution, in the event of material financial distress or failure.'" (quoting Dodd-Frank Act $\$ 165(\mathrm{~d}), 124$ Stat. at 1405 (codified at 12 U.S.C. $\S 5325(2012))))$.

49 The living-will requirement is unlikely, in any event, to eliminate systemic externalities caused by the failure of a TBTF firm. In my years as a workout and bankruptcy lawyer, I rarely saw a firm's failure that accurately reflected, much less closely resembled, expectations about the firm when it was profitable. Furthermore, living wills do not prevent the concurrent failure of multiple otherwise-TBTF firms from, collectively, having a systemic impact. Cf. Victoria McGrane, FDIC Chief: Big Failure Won't Harm the System, Wall St. J., May 12, 2015, at C1 (observing that some in Congress "doubt regulators could handle the failure of multiple major firms at the same time”). The financial crisis demonstrated that a concurrence of failures is likely when the causes of the failures are interconnected, such as an industry-wide overreliance on credit ratings. See Steven L. Schwarcz, Protecting Financial Markets: Lessons from the Subprime Mortgage Meltdown, 93 Minn. L. REv. 373, 379-83, 404-05 (2008); $c f$. Janet L. Yellen, Vice Chair of Bd. of Governors of the Fed. Reserve Sys., Remarks at the Annual Meeting of the National Association for Business Economics: Macropruden- 


\section{Volcker Rule}

In response to the financial crisis, former Federal Reserve Chairman Paul Volcker proposed that because bank deposits are federally guaranteed, deposit-taking banks should be restricted from making risky investments. ${ }^{50}$ This proposal became known as the "Volcker Rule."51 The substance of the Volcker Rule was implemented by the Dodd-Frank Act, which prohibits banks from (1) "engag[ing] in proprietary trading"52 or (2) "acquir[ing] or retain[ing] any equity, partnership, or other ownership interest in or sponsor[ing] a hedge fund or a private equity fund." 53

The Volcker Rule is also insufficient to control risk-taking that causes systemic externalities. Besides the Rule's limited application (to specific investments by banks), its regulatory rationale is microprudential, protecting the safety and soundness of individual firms. As with any other type of microprudential regulation, the Volcker Rule indirectly and partially reduces systemic risk by reducing the likelihood that an individual bank covered by the rule will fail; but it does not address correlations among failing firms, nor

tial Supervision and Monetary Policy in the Post-Crisis World 3 (Oct. 11, 2010) (transcript available at 2010 WL 3952044 (F.R.B.)) (attributing the financial crisis to concurrences of interrelated failures).

50 Paul Volcker, Op-Ed., How to Reform Our Financial System, N.Y. Times (Jan. 30, 2010), http://www.nytimes.com/2010/01/31/opinion/31volcker.html?pagewanted=all.

51 David Cho \& Binyamin Appelbaum, Obama's 'Volcker Rule' Shifts Power away from Geithner, WASH. Post (Jan. 22, 2010), http://www.washingtonpost.com/wp-dyn/content/ article/2010/01/21/AR2010012104935.html.

5212 U.S.C. $\$ 1851(\mathrm{a})(1)(\mathrm{A})$. "Proprietary trading" is defined as engaging as a principal for the trading account of the banking entity or [relevant] nonbank financial company . . . in any transaction to purchase or sell, or otherwise acquire or dispose of, any security, any derivative, any contract of sale of a commodity for future delivery, any option on any such security, derivative, or contract, or any other security or financial instrument that the appropriate Federal banking agencies, the Securities and Exchange Commission, and the Commodity Futures Trading Commission ... determine [by rule].

Id. $\S 1851(\mathrm{~h})(4)$. Reference to a "trading account" is intended to primarily cover shortterm trades, though federal regulators could expand that coverage. See id. $\$ 1851(\mathrm{~h})(6)$ (defining a trading account as "any account used for acquiring or taking positions in the securities and instruments [described in the definition of proprietary trading] principally for the purpose of selling in the near term (or otherwise with the intent to resell in order to profit from short-term price movements), and any such other accounts as the appropriate Federal banking agencies, the Securities and Exchange Commission, and the Commodity Futures Trading Commission ... determine [by rule]").

$53 I d . \S 1851(\mathrm{a})(1)(\mathrm{B})$. Notwithstanding these restrictions, trading is permitted "in connection with underwriting or market-making-related activities," to the extent that either does not "exceed the . . . near term demands of clients, customers, or counterparties"; "on behalf of customers"; or by an insurance business "for the general account of the [insurance] company.” See id. \$§ 1851(d)(1)(B), (D), (F). 
does it address the reasons why firms may want to engage in excessive risktaking or how to protect the financial system as a system. ${ }^{54}$

\section{E. Firm-Specific Financial Requirements}

In theory, firm-specific financial requirements, such as capital and solvency requirements, could help to control excessive corporate risk-taking by systemically important firms. ${ }^{55}$ For example, some of the largest systemically important firms are believed to have a funding advantage, "deriv[ing] from the belief of some creditors that the government might act to prevent [such a firm] from defaulting on its debts." 56 That funding advantage "creates an incentive for [those firms] to take on even more leverage and make themselves even more systemic (in order to increase the value of the [funding advantage] subsidy)." 57 Imposing a financial surcharge on those systemically important firms could, if calibrated correctly, "offset [that] subsidy and thereby cancel out these undesirable effects." 58

In practice, however, governments have not been using firm-specific financial requirements to control excessive corporate risk-taking because that "would require more precision ... than is now attainable."59 Instead, firmspecific financial requirements are being imposed to try to make systemically important firms more internally robust, so (as is the goal of TBTF regulation $^{60}$ ) they will be less likely to need a government bailout if they suffer

54 See supra note 15; see also Crawford, supra note 7, at 116 ("While prudential oversight is extremely important for addressing bank-like risks, it has never been enough on its own to prevent panics."). The Volcker Rule may also be counterproductive. Moody's has warned, for example, that it might "diminish the flexibility and profitability of banks' valuable market-making operations and place them at a competitive disadvantage to firms not constrained by the rule." Edward Wyatt, Regulators to Set Forth Volcker Rule, N.Y. Times (Oct. 10, 2011), http://www.nytimes.com/2011/10/11/business/volcker-rule-to-take-shape-thisweek.html; see also George W. Madison et al., Reconsidering Three Dodd-Frank Initiatives: The Volcker Rule, Limitations on Federal Reserve Section 13(3) Lending Powers, and SIFI Thresholds, 34 Banking \& Fin. Servs. Pol'y Rep., no. 6, 2015, at 6-7 (arguing that the Volcker Rule will not mitigate systemic risk because its effect will be to move trading activity from banks, which are subject to capital and liquidity requirements, to other market participants that are not subject to the same prudential regulation; and that restricting banks from engaging in proprietary trading may actually aggravate liquidity problems). The ultimate value of the Volcker Rule will be an empirical question: whether the benefits of its limitation on proprietary trading will outweigh profits lost by losing the ability to engage in such trading.

55 But cf. E.J. Kane, Hair of the Dog That Bit Us: The Insufficiency of New and Improved Capital Requirements, in The First Great Financial Crisis of the 21st Century: A RetroSPECTIVE 377, 377 (James R. Barth \& George G. Kaufman eds., 2016) (arguing that forcing systemically important financial institutions (SIFIs) to show more accounting capital will do little to curb their enhanced appetite for risk-taking that could cause the firm's failure).

56 Board of Governors of the Federal Reserve System, supra note 8, at 13.

57 Id.

$58 I d$.

$59 I d$.

60 See supra note 47 and accompanying text. 
losses-whether or not those losses are caused by excessive risk-taking. ${ }^{61}$ Because this focus of firm-specific financial requirements does not purport to control excessive corporate risk-taking, it is not central to this Article's analysis. ${ }^{62}$

It nonetheless may be worth observing that this focus of firm-specific financial requirements is unlikely to eliminate systemic externalities. While making systemically important firms more internally robust should partially reduce systemic risk by reducing the likelihood that any given firm will fail, these requirements are effectively microprudential-regulating the safety and soundness of individual firms. ${ }^{63}$ Firm-specific financial requirements do not purport to (macroprudentially) protect the integrity of the financial system as a system. Such financial requirements might also be counterproductive, making firms that are subject to them less competitive, ${ }^{64}$ driving "credit

61 Board of Governors of the Federal Reserve System, supra note 8, at 2. The Federal Reserve has also characterized this use of firm-specific financial requirements as reducing a systemically important firm's "systemic footprint." Id. at iii.

62 This Article focuses on controlling excessive corporate risk-taking as a means of reducing systemic externalities. As discussed above, see supra notes 47-49 and accompanying text, other regulatory approaches to try to reduce systemic externalities are not central to this Article's analysis. Other such regulatory approaches include the use of contingent capital regulation to convert debt claims of a troubled firm into equity interests, thereby reducing the likelihood that the firm will default, and the FDIC-inspired strategy for administratively resolving a large complex financial institution. Cf. Mike Konczal, Sheila Bair: Dodd-Frank Really Did End Taxpayer Bailouts, WAsh. Post (May 18, 2013), http://www .washingtonpost.com/blogs/wonkblog/wp/2013/05/18/sheila-bair-dodd-frank-really-didend-taxpayer-bailouts / " $[\mathrm{T}]$ he FDIC has come up with a viable strategy for resolving a large complex financial institution. . . . The FDIC will take control of a holding company and put creditors and shareholders into a receivership where they, not taxpayers, will absorb any losses. This will allow the subsidiaries to remain operational, avoiding systemic disruptions, as the overall entity is unwound over time.”).

63 See supra note 15; cf. supra note 36 and accompanying text (making a similar observation in the context of contingent capital regulation); Daniel Schwarcz \& Steven L. Schwarcz, Regulating Systemic Risk in Insurance, 81 U. CHI. L. Rev. 1569, 1580 (2014) (observing that although "solvency regulation ... attempts to safeguard the financial strength of individual insurers . . . the core goal of even solvency regulation has long been understood to be protecting consumers by ensuring that insurers have the financial capacity to pay policyholder claims when they become due" (footnote omitted)).

64 Cf. Nabila Ahmed \& Sridhar Natarajan, Jefferies Is Poaching the Big Banks' Loan Business with Help from the Fed, BloOMBERG (May 29, 2015), http://www.bloomberg.com/news/ articles/2015-05-29/jefferies-poaching-big-banks-loan-business-with-help-from-fed (reporting that unregulated hedge funds "step in to fill a void" when regulated banks are restricted from fulfilling market needs); Eduardo Porter, Recession's True Cost Is Still Being Tallied, N.Y. Times (Jan. 21, 2014), http://www.nytimes.com/2014/01/22/business/economy/the-cost-of-the-financial-crisis-is-still-being-tallied.html (observing that regulations that require financial institutions to increase capital cushions to buffer against risks and potential losses have been criticized for cutting into global economic output and reducing jobs). The potential for firm-specific financial requirements to make firms less competitive is a result of Congress' "mandate provided by the Dodd-Frank Act, which instructs the [Federal Reserve] Board to mitigate risks to the financial stability of the United States" 
intermediation to the less-regulated shadow banking sector," 65 misleading regulators about safety, ${ }^{66}$ creating "perverse incentives," 67 and inadvertently hurting the economy. ${ }^{68}$

\section{Redesigning Regulation}

For the reasons discussed above, the regulatory responses to the financial crisis that purport to mitigate excessive corporate risk-taking by systemically important firms are unlikely to be sufficient to control risk-taking that causes systemic externalities. As a result, that risk-taking is likely to continue. Indeed, those regulatory responses may be insufficient to control risk-taking that hurts the firm's interests, much less the public's interests. For example, almost half of the thirty-six banks covered in a recent Financial Stability Board survey failed to meet the "'fundamental' criteria for sound risk governance." ${ }^{69}$ And J.P. Morgan Chase, UBS, and Barclays suffered huge losses from excessive risk-taking or lack of risk-taking oversight. ${ }^{70}$

Whether or not more should be done to control risk-taking that hurts the firm's interests, ${ }^{71}$ more certainly should be done, in principle, to control

without consideration of costs and benefits. BoARd of Governors of the Federai Reserve System, supra note 8 , at 13 .

65 Board of Governors of the Federal Reserve System, supra note 8, at 13.

66 Cf. Emilios Avgouleas, Bank Leverage Ratios and Financial Stability: A Micro- and Macroprudential Perspective 3 (Levy Econ. Inst. of Bard Coll. Working Paper No. 849, 2015) (observing that federal regulators were misled about banking safety prior to the financial crisis because the required bank leverage ratio "totally failed to capture the perilous state of the US banks in [that] period").

$67 I d$. at 12-13. Professor Avgouleas argues " $[\mathrm{t}]$ here is evidence that leverage restrictions may not reduce risk" because "bank managers may be incentivized into choosing [riskier] assets with more highly correlated returns"-thereby creating "perverse incentives." Id. He additionally argues that even the new Basel III capital requirements create "uncertainty [that] severely undermines rather than reinforces market discipline" because "the Basel system of risk weights" is "excessively complex and highly difficult to understand [and also] susceptib[le] to gaming." Id. at 16-17. That uncertainty, in turn, "will lead to a near certain loss of confidence in the banking system" in the event of a crisis. Id. at 17 .

68 See, e.g., Steven L. Schwarcz, Regulating Financial Change: A Functional Approach, 100 MinN. L. Rev. 1441, 1466 (2016) (observing that countercyclical capital requirements may not be feasible because it is "virtually impossible to know ex ante whether a financial cycle is rational or merely a bubble"; and discussing how the misapplication of such firm-specific financial requirements led to the savings and loan (S\&L) crisis of the 1980s).

69 Jim Brunsden, Banks Must Boost Risk Oversight After Trading Scandals, FSB Says, BloomberG (Feb. 12, 2013), http://www.bloomberg.com/news/articles/2013-02-12/ banks-must-boost-risk-oversight-after-trading-scandals-fsb-says (quoting Fin. STABility BD., Thematic Review on Risk Governance Peer Review Report 2 (Feb. 12, 2013), http://www .fsb.org/wp-content/uploads/r_130212.pdf).

70 Id. In 2012, a J.P. Morgan trader, aptly nicknamed the London Whale for his big positions, caused the bank to report its biggest-ever trading loss of $\$ 6.2$ billion. Also in 2012, UBS suffered the largest loss from unauthorized trading in U.K. history, $\$ 2.3$ billion, when one of its traders was convicted of fraud and sentenced to prison. Id.

71 This Article does not focus on that question per se; it focuses instead on risk-taking that harms the public's interests. 
excessive corporate risk-taking that causes systemic externalities. Section A below explains why regulation should be appropriate for that purpose, even though it is inappropriate to control most other externalities that result from corporate risk-taking. Sections B and $\mathrm{C}$ then examine and compare regulating-substance and regulating-governance options to control excessive corporate risk-taking that causes systemic externalities. Although financial regulation traditionally regulates substance (such as imposing capital-adequacy standards), ${ }^{72}$ systemic risk regulation should additionally focus on regulating a firm's governance to better align private and public interests.

\section{A. Additional Regulation Is Needed}

Although in principle more should be done to control excessive corporate risk-taking that causes systemic externalities, one cannot merely assume that additional regulation is justified. Corporate risk-taking routinely causes externalities, ${ }^{73}$ yet regulation controls few of those externalities. ${ }^{74}$ Regulation cannot, realistically, control all corporate externalities. ${ }^{75}$

Nonetheless, for at least three reasons, ${ }^{76}$ regulation should require firms to mitigate their systemic externalities. First, systemic externalities "can cause

72 See infra Section II.B.

73 Steven L. Schwarcz, Collapsing Corporate Structures: Resolving the Tension Between Form and Substance, 60 Bus. LAw. 109, 144 (2004). Most of "a corporate structure's externalities result from the limited-liability rule of corporation law." Id. For an analysis of whether that rule itself should be limited, see Schwarcz, infra note 77. Limiting that rule would regulate the shareholder principals whose agents, the managers of systemically important firms, this Article seeks to regulate.

74 Cf. Michael J. Trebilcock, The Limits of Freedom of Contract 58 (1993) ("Even if both parties to a particular exchange benefit from it, the exchange may entail the imposition of costs on non-consenting third parties. . . The problem of third-party effects from exchange relationships is pervasive and not aberrational. Almost every transaction one can conceive of is likely to impose costs on third parties."). For arguments that corporate law should be used to control externalities, see Lawrence E. Mitchell, The Legitimate Rights of Public Shareholders, 66 WASH. \& LeE L. Rev. 1635, 1665-66 (2009) (arguing that because "creditors were providing the bulk of the risk capital," "[m]anagerial incentives can be distorted significantly by the existing regime of shareholder participation rights").

75 Cf. Trebilcock, supra note 74, at 58 (explaining that if externalities resulting from everyday transactions justified prohibiting the exchange process or putting constraints upon it, then "freedom of contract would largely be at an end"); see also R.H. CoAse, ThE Firm, THE MARKET, AND THE LAW 24 (1988) (arguing that the existence of externalities does not establish a prima facie case for intervention because government regulation is also not without cost).

76 A fourth reason why regulation should require firms to mitigate their systemic externalities is that the financial crisis has established and solidified a norm that financial regulation should address and mitigate systemic risk. See, e.g., Harold S. Bloomenthal \& Samuel Wolff, Recent Developments in International Securities Regulation, 33 SEc. \& FED. Corp. L. REP., no. 11, 2011, at 1 (commenting that the United States has led the international financial regulatory community in implementing the reforms agreed upon by the Group of Twenty, or G-20, in the aftermath of the financial crisis, and describing this regulation as "focused on the familiar crisis and postcrisis themes of systemic and macroeconomic risk, including regulation and resolution of systemically important financial institutions (SIFIs) 
much more harm than non-systemic externalities." 77 Because they impact the real economy, ${ }^{78}$ systemic externalities can, for example, lead to "widespread poverty and unemployment."79 A prominent governor of the Federal Reserve similarly argues that "prudential regulation [should] need to involve itself with corporate governance" because "risk-taking" by systemically important financial intermediaries "carries substantial potential societal consequences." 80 Second, systemic externalities harm the public, as opposed to private stakeholders who could contract to protect themselves. ${ }^{81}$ Third, systemic externalities can, as this Article will show, realistically, pragmatically, and efficiently be mitigated. ${ }^{82}$

For these reasons, systemic externalities should be distinguished from other externalities for regulatory purposes. I next examine how regulation could further control corporate risk-taking that causes systemic externalities. $^{83}$

\section{B. Regulating Substance}

Regulation could control corporate risk-taking that causes systemic externalities by imposing specific regulatory requirements, ${ }^{84}$ by making certain actions illegal or tortious, or by imposing corporate governance duties

and global SIFIs (G-SIFIs), bank capital requirements and supervision, derivatives regulation, investment advisers, executive compensation, and rating agencies").

77 Steven L. Schwarcz, The Governance Structure of Shadow Banking: Rethinking Assumptions About Limited Liability, 90 Notre Dame L. Rev. 1, 21 (2014).

78 The "real economy" means the economic reality, such as a recession, that the public actually experiences. Schwarcz, supra note 7, at 206.

79 Id. at 207.

80 Daniel K. Tarullo, Governor, Fed. Reserve Sys., Remarks at the Association of American Law Schools Midyear Meeting: Corporate Governance and Prudential Regulation 7-8 (June 9, 2014); cf. Jonathan R. Macey \& Maureen O'Hara, The Corporate Governance of Banks, 9 Fed. Res. Bank N.Y. Econ. Pol'y Rev. 91, 97-98 (2003) (arguing that it may be economically efficient to modify the corporate governance of FDIC-insured banks to account for systemic risk).

81 Cf. Ian B. Lee, The Role of the Public Interest in Corporate Law, in Research Handbook on the Economics of Corporate Law 106, 115 (Claire A. Hill \& Brett H. McDonnell eds., 2012) (arguing that corporation law should be able to impose rules to protect the public, just as law otherwise protects the public — such as a municipal park rule that protects residents of the neighborhood from excessive noise).

82 See infra Section III.B.

83 In a prior article, I made a related but narrower inquiry. See Steven L. Schwarcz, Excessive Corporate Risk-Taking and the Decline of Personal Blame, 65 EмоRy L.J. 533 (2015). "This Article does not examine all forms of optimal regulation that could limit excessive risk-taking or its systemic consequences; its scope is limited to regulation that imposes personal liability to deter excessive risk-taking. Thus, the Article does not consider, for example, whether to break up systemically important firms." Id. at 540 n.26.

84 For an example of how regulatory requirements can drive contractual restrictions, see for example supra notes 35-40 and accompanying text (discussing how contingent capital regulation motivates contractual loan-covenant restrictions). 
on the managers of systemically important firms. ${ }^{85}$ This Article refers to imposing specific regulatory requirements and making certain actions illegal or tortious as "regulating substance," as discussed in this Section. In contrast, this Article refers to imposing corporate governance duties as "regulating governance," 86 which is discussed in Section C below.

Financial regulation traditionally regulates substance because regulating governance is thought to "weaken[ ] the wealth-producing capacities of the firm." ${ }^{77}$ The responses to the financial crisis discussed in Part I, for example-including those that are designed to control risk-taking by aligning managerial and investor interests-regulate substance. The capital-adequacy standards imposed on banks for decades under the Basel Accords regulate substance. ${ }^{88}$ As this Article has shown, however, regulating substance has so far proved insufficient to control the excessive corporate risk-taking that causes systemic externalities. ${ }^{89}$

85 See, e.g., Franklin A. Gevurtz, The Role of Corporate Law in Preventing a Financial Crisis-Reflections on In re Citigroup Inc. Shareholder Derivative Litigation, in Corporate Governance after the Financial Crisis 163, 168-75 (P.M. Vasudev \& Susan Watson eds., 2012).

86 Commentators have made a somewhat parallel distinction between external and internal regulation, the former referring to standards imposed on a firm and the latter referring to any interference with the firm's internal operations, including limiting executive compensation. See Lee, supra note 81, at 124. This Article's distinction between regulating substance and regulating governance-in which the latter refers only to regulating corporate governance procedures themselves-attempts to be more precise. Cf. id. at 124 (calling the distinction between external and internal regulation a "distinction without a difference"). For example, limiting executive compensation in prescribed ways would be regarded as regulating substance in this Article but as internal regulation under the external-internal distinction.

87 Id. at 124; see also Stephen M. Bainbridge, Corporation Law and Economics 425 (2002) (pointing out that negative externalities created by corporate conduct should be "constrained through general welfare legislation, tort litigation, and other forms of regulation”); Leo E. Strine, Jr. \& Nicholas Walter, Conservative Collision Course?: The Tension Between Conservative Corporate Law Theory and Citizens United, 100 Cornell L. Rev. 335, 380-81 (2015) (also contending that the most responsible, legitimate, and effective way to control externalities is to have the "legitimate instruments of the people's will, reflective of their desire, set the boundaries for corporate conduct"); cf. Milton Friedman, The Social Responsibility of Business Is to Increase Its Profits, N.Y. Times (Sept. 13, 1970), http://umich .edu/ thecore/doc/Friedman.pdf (arguing that managers lack the political legitimacy and expertise to consider social interests). In principle, I agree with these arguments, especially where the regulation concerns routine externalities or externalities as to which private parties could contract to protect themselves.

88 See, e.g., Heath Price Tarbert, Note, Are International Capital Adequacy Rules Adequate? The Basle Accord and Beyond, 148 U. PA. L. Rev. 1771, 1778-86 (2000) (stating that the "capital adequacy standards for commercial banks . . prescribed a substantive set of riskbased capital adequacy standards").

89 See supra notes 54-70 and accompanying text. 
Commentators have proposed other possible ways to regulate substance to help control that corporate risk-taking. ${ }^{90}$ For example, regulation could require systemically important firms to pay into a fund that would be used to help offset systemic risks and costs. ${ }^{91}$ This would not only help to internalize externalities; it also would motivate systemically important firms to monitor each other, in order to avoid having to pay more into the fund, thereby helping control each other's risky behavior. ${ }^{92}$ Federal Deposit Insurance Corporation (FDIC) deposit insurance provides a precedent for this type of a fund. ${ }^{93}$

Although such a requirement theoretically could help to control excessive corporate risk-taking that causes systemic externalities, it may not be feasible in the near future. Politically, although such a requirement was in the bill that became the Dodd-Frank Act, it was deleted because certain members of Congress felt (incorrectly in the author's opinion) that the very creation of a systemic risk fund would itself increase moral hazard. ${ }^{94}$ Practically, such a requirement would need further analysis of, and also would need a consensus on, how to calculate the required contributions. Such calculations would be needed both to make the size of the fund sufficiently viable for its purpose and also to allocate the required contributions among the wide range of systemically important firms. ${ }^{95}$

90 Only one country, in a limited banking context, has proposed imposing criminal illegality. The U.K.'s Financial Conduct Authority and the Bank of England's regulatory arm, the Prudential Regulation Authority, have proposed regulations that would impose personal criminal liability on bankers of a failed bank unless they could prove that they acted appropriately. Jill Treanor, Regulators Want Reckless Bankers to be Criminally Liable Under New Plans, GuARdian (July 30, 2014), http://www.theguardian.com/business/2014/ jul/30/regulators-want-bankers-to-accept-criminal-liability. In protest, bank directors have been threatening to quit. See, e.g., Sean Farrell, HSBC Directors to Quit Over Threat to Jail Bosses for Banking Crises, GuARDiAn (Oct. 7, 2014), http://www.theguardian.com/business/ 2014/oct/07/hsbc-directors-quit-jail-bank-crises.

91 Anabtawi \& Schwarcz, supra note 40, at 102-03; Anabtawi \& Schwarcz, supra note 46, at 1402. This type of regulation ideally should be global to avoid prejudicing the competitiveness of firms subject to United States regulatory requirements.

92 Anabtawi \& Schwarcz, supra note 40, at 102-03; Anabtawi \& Schwarcz, supra note 46, at 1402; see also Jeffrey N. Gordon \& Christopher Muller, Confronting Financial Crisis: Dodd-Frank's Dangers and the Case for a Systemic Emergency Insurance Fund, 28 YALE J. ON REG. 151, 210 (2011) (arguing that a systemic risk fund "amounts to a mutualization of risk that should encourage more cautious firms to press regulators to rein in firms and practices that pose systemic risks").

93 Anabtawi \& Schwarcz, supra note 40, at 102-03; Anabtawi \& Schwarcz, supra note 46 , at 1402 .

94 Gordon \& Muller, supra note 92, at 208; see also Steven L. Schwarcz, Identifying and Managing Systemic Risk: An Assessment of Our Progress, 1 Harv. Bus. L. Rev. Online 94, 103 (2011).

95 Cf. Steven L. Schwarcz, Too Big To Fail?: Recasting the Financial Safety Net, in ThE Panic of 2008: Causes, Consequences and Implications for Reform 94, 108 nn.40-41 (Lawrence E. Mitchell \& Arthur E. Wilmarth, Jr., eds., 2010) (discussing these practical considerations, and also suggesting that-so long as each contributing firm has enough 
Commentators have also suggested a so-called "Pigouvian tax" as another possible way to help control, or at least to help internalize the systemic impact of, excessive corporate risk-taking. This is a tax designed to "offset the effects of [a systemically important] bank's actions on wider society." 96 Along these lines, the Financial Stability Board (FSB) has proposed imposing a "systemic [capital] surcharge" on the largest banks. ${ }^{97}$

The practicality of a Pigouvian tax is unclear. At least as proposed as a capital surcharge, it could be difficult to impose on a systemically important nonbank. ${ }^{98}$ Imposing such a surcharge on a bank would also be imperfect, economists argue, because a capital surcharge is used to achieve two (sometimes) incompatible goals_- "as a buffer against unexpected loss [and to] limit risk taking."99 To the extent it serves as a buffer against unexpected loss, a Pigouvian tax would simply be a type of firm-specific financial requirement, which would not be central to this Article's analysis. ${ }^{100}$

Tort law is also unlikely to control excessive corporate risk-taking that causes systemic externalities. As a form of public control through the common law system of privately enforced rights, ${ }^{101}$ tort law has long been a fundamental tool to impose personal civil liability to remedy harm for unreasonable risk-taking. ${ }^{102}$ Its utility is limited, however, to remedying foreseeable harm. ${ }^{103}$ But systemic harm is rarely foreseeable.

Systemic harm instead affects a wide range of third parties in unpredictable ways. Consider, for example, an individual who is forced to close her family-owned restaurant during a systemically-caused recession. Or taking a more concrete example from the financial crisis, consider whether to impose tort liability on a manager of a financial firm who, in the expectation of a bonus, sells highly-leveraged types of risky asset-backed securities to sophisticated investors, contributing to that crisis. Tort law could not-and assum-

capital at risk in the fund-the government could supplement the fund to ensure that its size is sufficiently viable).

96 Gianni De Nicoló et al., Externalities and Macroprudential Policy, 2 J. Fin. PErsp. 95 , 103 (2014); Andrew G. Haldane, On Being the Right Size, 2 J. Fin. Persp. 13, 16 (2014).

97 See, e.g., Haldane, supra note 96 , at 16-17 (stating that a capital surcharge of over $7 \%$ would "remove $90 \%$ of the systemic externality").

98 Beatrice Weder di Mauro et al., Three Birds with One Stone: The G20 and Systemic Externalities, VoxEU (June 26, 2010), http://www.voxeu.org/article/three-birds-one-stone-g20and-systemic-externalities.

$99 \quad I d$.

100 See supra note 62 and accompanying text.

101 Richard A. Posner, Economic Analysis of Law 383 (6th ed. 2003) (observing that there are "two methods of public control-the common law system of privately enforced rights and the administrative system of direct public control").

102 See, e.g., Gevurtz, supra note 85, at 127 (observing that the concept of "[i]mposing liability to pay the damages resulting from unreasonable risks . . is a pillar of tort law").

103 Restatement (Third) of Torts: Phys. \& Emot. Harm $\$ 3$ (Ам. Law Inst. 2016) ("To establish . . . negligence, it is not enough that there be a likelihood of harm; the likelihood must be foreseeable to the actor at the time of conduct."). 
ing legally sufficient disclosure, probably should not-be used to impose personal liability on that manager for the resulting systemic harm. ${ }^{104}$

Regulating substance therefore is important, but it may be insufficient to control excessive corporate risk-taking that causes systemic externalities. ${ }^{105}$ To continue to limit financial regulation to regulating substance would therefore create what Professor Ian Lee has called a "regulatory dysfunction." 106 To avoid that dysfunction, I next examine whether regulating governance could help to control that excessive risk-taking without weakening corporate wealth-producing capacity. ${ }^{107}$

\section{Regulating Governance}

Although regulating substance generally should be superior to government interference with corporate governance to control externalities, regulating substance has so far proved insufficient-and is unlikely to become sufficient in the near future-to control the excessive corporate risk-taking that causes systemic externalities. ${ }^{108}$ That insufficiency may well reflect the reality that excessive corporate risk-taking primarily results from managerial judgment calls. For example, the excessive corporate risk-taking that led to the financial crisis "largely resulted from poor decisions, bad judgment, and greed." 109

To control that risk-taking, regulation also needs to regulate governance. ${ }^{110}$ In making corporate decisions, managers currently have a duty to

104 Cf. Armour \& Gordon, supra note 37, at 46-47 (explaining that tort law usually does not allow recovery for indirect losses, and also observing that it is difficult to impose tort liability on a bankrupt firm).

$105 C f . i d$. at 38 (concluding that "it is unsafe to rely on regulation [that regulates substance] alone").

106 E-mail from Ian B. Lee, Assoc. Prof., Univ. of Toronto Faculty of Law, to the author (Aug. 18, 2015) (on file with author) (observing that "if existing legal obligations are an important part of the problem, then we are in the presence of a regulatory dysfunction and not a market dysfunction. A logical possibility exists that the solution is not to introduce a further intervention (new legal obligations), but rather to remove or alter the existing intervention ... that is, to weaken the managers' existing legal duty to shareholders").

107 Cf. supra note 87 and accompanying text (stating the argument against regulating governance).

108 Cf. David T. Llewellyn, Some Lessons for Bank Regulation from Recent Financial Crises, in Handbook of International Banking 428, 429 (Andrew W. Mullineux \& Victor Murinde eds., 2003) ("While external regulation has a role in fostering a safe and sound banking system, this role is limited" and "increasingly important, are . . corporate governance arrangements within banks.").

109 Schwarcz, supra note 83, at 538.

110 Cf. Griffith, supra note 6, at 1227 (recommending that derivatives clearinghouses maintain "a separate governing body with a public charge-the containment of systemic risk”); Peter O. Mülbert, Managing Risk in the Financial System, in The Oxford Handbook of Financial Regulation 365, 385 (Niamh Moloney et al. eds., 2015) (suggesting that the management of financial institutions be required "to take into account the negative external effects of their decisions on other financial institutions and, thus, the contribution to increasing systemic risk and reducing financial stability"); Tarullo, supra note 80, at 9 
the firm and its investors. To reduce systemic externalities, they should also have a duty to society (hereinafter, a "public governance duty"111) not to engage their firms in excessive risk-taking that leads to those externalities. ${ }^{112}$ So long as it does not unduly weaken wealth-producing capacity, regulating governance in this way would help to align private and public interests. ${ }^{113}$

In the financial context, regulating governance has another advantage over regulating substance. Regulating substance often depends on regulators precisely understanding the financial "architecture"-the particular design and structure of financial firms, markets, and other related institutions-at the time the regulation is promulgated. ${ }^{114}$ Because the financial architecture is constantly changing, ${ }^{115}$ that type of grounded regulation has value as long as it is updated as needed to adapt to those changes. ${ }^{116}$ But ongoing financial monitoring and regulatory updating can be costly and "is subject to political interference at each updating stage."117 As a result, finan-

(arguing "for prudential regulation to influence the processes of risk-taking" to complement "capital requirements and other substantive measures").

111 This Article contemplates an actual duty on the part of a firm's managers, in contrast to mere managerial discretion, to not engage their firms in excessive risk-taking that leads to systemic externalities. Cf. Einer Elhauge, Sacrificing Corporate Profits in the Public Interest, 80 N.Y.U. L. REv. 733 (2005) (arguing for managerial discretion to act in the social interest).

112 An alternative to imposing a public governance duty on a firm's managers might be to designate one or more managers ("public advocates") whose primary duty would be to represent the public, preserving the other managers' traditional duties with one exception: in any decisionmaking, the other managers would have the right to take into account the public advocate's viewpoint. Cf. Steven L. Schwarcz, Rethinking Corporate Governance for a Bondholder Financed, Systemically Risky World, 58 WM. \& MARY L. REV. (forthcoming 2016-17) (arguing that because bond financing now dwarfs equity financing and bond prices are tied to firm performance, corporate governance should include bondholders, and suggesting that including bondholders in corporate governance could help to reduce systemic risk because bondholders are more risk averse than shareholders).

113 There is banking precedent that purports to regulate governance to align private and public interests, but it is more precatory than real. The Basel Committee on Banking Supervision sets corporate governance guidelines for banks in order to "safeguard [ ]. . . interest in conformity with public interest on a sustainable basis." BASEL COMM. ON BANKing Supervision, Guidelines: Corporate Governance Principles for Banks 3 (2015), http://www.bis.org/bcbs/publ/d328.pdf. These guidelines, however, merely require banks to "protect the interests of depositors, meet shareholder obligations, and take into account the interests of other recognised stakeholders." Id. For an argument in favor of regulating governance to minimize corporate environmental externalities, see Gail E. Henderson, A Fiduciary Duty to Minimize the Corporation's Environmental Impacts (Univ. of Oslo Faculty of Law, Legal Studies Research Paper No. 2011-32, 2011).

114 Schwarcz, supra note 68, at 1443.

115 Id.

116 Cf. Perry Mehrling, The New Lombard Street: How the Fed Became the Dealer OF LAST RESORT 4-5 (2011) (arguing that because economics and finance "largely ignore the sophisticated mechanism that operates to channel cash flows . . to meet cash commitments," they have not "been particularly well suited for understanding the . . [ [financial] crisis during which the crucial monetary plumbing broke down").

117 Schwarcz, supra note 68 , at 1443 . 
cial regulation of substance usually lags financial innovation, ${ }^{118}$ causing unanticipated consequences and allowing innovations to escape regulatory scrutiny. ${ }^{119}$

Regulating governance, in contrast, can overcome that regulatory time lag. If the firm is proposing to engage in a risky project that represents financial innovation, its managers either have or, to fulfill their governance duties, must try to obtain the most current information about the innovation and its consequences.

\section{Towards Regulatory Alignment: A Public Governance Duty}

To help control the excessive corporate risk-taking that leads to systemic externalities, this Article has shown that regulating governance has an advantage over, and therefore in principle should supplement, regulating substance-so long as it does not unduly weaken corporate wealth-producing capacity. Subject to that proviso, managers should have a public governance duty not to engage their firms in excessive risk-taking that leads to those externalities. Because only systemically important firms, by definition, could engage in risk-taking that leads to systemic externalities, the public governance duty should apply only to managers of those firms.

Section A below analyzes such a public governance duty under corporate governance legal theory. Thereafter, Section B shows how the duty could be feasibly and efficiently implemented, without unduly weakening corporate wealth-producing capacity. The Appendix to the Article then proposes possible model language, in the form of a Public Governance Duty Act, for regulation imposing the duty.

\section{A. Analyzing a Public Governance Duty Under Corporate Governance Legal Theory}

Except to the extent it intentionally limits shareholder primacy, a public governance duty that aligns a systemically important firm's interests with the public's interests should not be inconsistent with corporate governance legal theory. As explained below, it should be consistent with the stakeholder model of governance, because the public is a stakeholder whom the law should protect against systemic externalities. It should be consistent with the

118 Id. at 1454; see also Edward J. Kane, Policy Implications of Structural Changes in Financial Markets, 73 Am. Econ. Rev. 96 (1983) (arguing that regulatory responses lag behind innovations).

119 This occurred in 2008, for example, when the pre-crisis financial regulatory framework, which assumed the dominance of bank-intermediated funding, failed to adequately address a collapsing financial system in which the majority of funding had become nonbank-intermediated. Cf. Julia Black, Restructuring Global and EU Financial Regulation: Character, Capacities, and Learning, in Financial Regulation and Supervision: A Post-Crisis ANAlysis 3, 13 (Eddy Wymeersch et al. eds., 2012) ("[T] he system simply did not operate in the way that regulators, banks, and economists had thought it did. If you do not understand how the system works, it is very hard to build in mechanisms either for managing risk or for ensuring the system's resilience when those risks crystallize.”). 
more generally accepted contractarian model of governance because, even though the public is not a contracting party, systemic externalities are exactly the type of externalities that should count in limiting freedom of contract that harms non-contracting parties. And although it technically would be inconsistent with the shareholder-primacy model, even that model recognizes the need to control certain externalities-and a public governance duty may be the best way to control the excessive corporate risk-taking that causes systemic externalities.

\section{The Stakeholder Model of Governance}

A public governance duty should most clearly be consistent with the stakeholder model of governance. Under this model, the interests of everyone affected by a firm's actions should be considered, to avoid anyone's interest being unfairly exploited. ${ }^{120}$ The public, of course, is affected by a firm's risk-taking. ${ }^{121}$ This model, however, adds little explanatory value because there is fundamental disagreement on the extent to which non-investor stakeholder interests should be taken into account, valued, and balanced with shareholder interests. ${ }^{122}$

Judicial opinions in the United States and Canada illustrate this disagreement. In Metropolitan Life Insurance Co. v. RJR Nabisco, Inc., ${ }^{123}$ plaintiff MetLife argued that RJR's leveraged buyout caused the RJR bonds held by MetLife to lose their investment-grade rating, ${ }^{124}$ thereby violating an implied covenant to bondholders. ${ }^{125}$ As a consequence of the rating downgrade, the

120 Henry Hansmann \& Reinier Kraakman, The End of History for Corporate Law, 89 GEO. L.J. 439, 447 (2001) (explaining that stakeholders may include "employees, creditors, customers, merchants ... or even broader interest groups such as beneficiaries of a wellpreserved environment”). But cf. Lee, supra note 81, at 111 (suggesting that stakeholder theory does not necessarily imply that the firm has no bounds, i.e., that there is no distinction between the firm and the public; it need only mean that the firm's interests are not coextensive with those of the shareholders).

121 Cf. Zhong Xing Tan, Stewardship in the Interests of Systemic Stakeholders: Re-conceptualizing the Means and Ends of Anglo-American Corporate Governance in the Wake of the Global Financial Crisis, 9 J. Bus. \& TECH. L. 169, 179-89 (2014) (arguing that the financial system and economy qualify as stakeholders under a risk-based model of stakeholding).

122 Cf. Douglas G. Baird, Bankruptcy's Uncontested Axioms, 108 Yale L.J. 573, 578 (1998) (observing a similar type of debate in bankruptcy law, in which different parties to the debate start with very different norms).

123716 F. Supp. 1504 (S.D.N.Y. 1989).

124 For a description of how bond ratings are structured, see Steven L. Schwarcz, Private Ordering of Public Markets: The Rating Agency Paradox, 2002 U. ILL. L. Rev. 1, 7 (2002) (" $[\mathrm{T}]$ he highest rating on long-term debt securities is AAA, with ratings descending to AA, then to $\mathrm{A}$, and then to $\mathrm{BBB}$ and below. . . . The higher the rating, the lower the rating agency has assessed the credit risk associated with the securities in question. . . 'Ratings below BBB- are deemed non-investment grade, and indicate that full and timely repayment on the securities may be speculative." (footnotes omitted) (quoting Steven L. Schwarcz, The Universal Language of Cross-Border Finance, 8 Duke J. Comp. \& InT'L L. 235, 253 (1998))).

125 RJR Nabisco, 716 F. Supp. at 1516. 
resale value of the bonds plummeted. ${ }^{126}$ MetLife argued that its damages should include this loss in market value, but the court declined to recognize that loss as legally compensable. ${ }^{127}$ The court implicitly acknowledged the possibility that the bondholders were affected stakeholders. It refused, however, to order compensation for the resulting externalities. ${ }^{128}$

The authority most clearly expressing a stakeholder model is the celebrated Canadian case of BCE, Inc. v. 1976 Debentureholders, ${ }^{129}$ the facts of which are virtually identical to those in Metropolitan Life Insurance Co. v. RJR Nabisco, Inc. Plaintiff-debentureholders argued that BCE's board of directors had acted inappropriately in agreeing to a leveraged buyout that would have caused the debentures to lose their investment-grade rating, thereby diminishing their value. ${ }^{130}$ The court observed that the debentureholders were warned that they could not reasonably expect the investment-grade rating to be maintained, nor did they include indenture covenants to try to protect the rating. ${ }^{131}$ Nonetheless, the court's opinion broadly articulated a stakeholder model of governance:

Where conflicting interests arise, it falls to the directors of the corporation to resolve them in accordance with their fiduciary duty to act in the best interests of the corporation. ... There are no absolute rules and no principle that one set of interests should prevail over another. In each case, the question is whether, in all the circumstances, the directors acted in the best interests of the corporation, having regard to all relevant considerations, including — but not confined to- the need to treat affected stakeholders in a fair manner, commensurate with the corporation's duties as a responsible corporate citizen. ${ }^{132}$

One prominent commentator, quoting a prior Canadian decision, observes that such a stakeholder model of governance could even take into account "the interests of, inter alia, shareholders, employees, creditors, consumers, governments and the environment." 133 Even in Canada, however, there remains fundamental disagreement about how to apply a stakeholder model of governance, including how to determine which stakeholders' interests should be taken into account and how managers of firms could attempt to value and balance those interests with investor interests.

\footnotetext{
126 Id. at 1506.

127 Id. at 1518.

$128 I d$. The court's articulated reasoning was somewhat tortured: the market-value loss did not constitute the "fruits of the agreement" under which the bonds were issued because the "substantive 'fruits' [of a bond indenture only] . . . include the periodic and regular payment of interest and the eventual repayment of principal," which were expected to continue even after RJR's leveraged buyout. Id. at 1518-19.

129 [2008] 3 S.C.R. 560 (Can.).

$130 I d$. at 563.

$131 I d$. at 565.

$132 I d$.

133 Robert Yalden, Canadian Mergers and Acquisitions at the Crossroads: The Regulation of Defence Strategies After BCE, 55 CAN. Bus. L.J. 389, 407 (2014).
} 
The Article next argues, in the context of discussing the contractarian model of governance, that this disagreement reflects a larger uncertainty about the extent to which law should protect third parties from externalities. ${ }^{134}$ That larger uncertainty is a fundamental inquiry of contract law. Insights from contract law can help to reveal, at least in the context of systemic externalities, how that uncertainty can be resolved.

\section{The Contractarian Model of Governance}

This model reflects the most widely accepted theory of corporate governance-that a firm is a "nexus of contracts" among private parties. ${ }^{135}$ The corporate governance rules are priced as part of the contractual negotiation. ${ }^{136}$ At first glance, a public governance duty would appear to be inconsistent with this model. After all, members of the public are not contracting parties.

Contract law, however, does not limit its application to contracting parties. Freedom of contracting is not, and should not be, absolute. Government should be able to limit it in at least three scenarios, ${ }^{137}$ one of which is when the contracting causes externalities. ${ }^{138}$ The critical question is which externalities should count in limiting that freedom. ${ }^{139}$

Even under contract law, there is no absolute answer to that question. ${ }^{140}$ Some scholars have therefore dismissed externalities as a basis for regulation. ${ }^{141}$ But this Article need answer only a much more limited question: Should systemic externalities count in limiting freedom of contract? That question has already been answered in a separate context. ${ }^{142}$ Systemic externalities not only harm the public, who cannot contract to protect them-

134 Cf. Trebilcock, supra note 74, at 20 (identifying the "major conceptual" problem of "[d] etermining ... which [externalities] are to count in constraining the ability of parties to contract with each other"). After all, the stakeholder-model debate ultimately turns on the extent to which law should require a firm's managers to protect non-investor parties who could be impacted by a corporate action.

135 Frank H. Easterbrook \& Daniel R. Fischel, The Corporate Contract, 89 Colum. L. Rev. 1416, 1426 (1989).

136 Id. at 1430.

137 See, e.g., Steven L. Schwarcz, Rethinking Freedom of Contract: A Bankruptcy Paradigm, 77 Tex. L. Rev. 515 (1999) (arguing that freedom of contract should be subject to statutory policies, paternalism, and material externalities).

138 Id. at 520-21.

139 Trebilcock, supra note 74, at 58-59 (raising that question).

$140 I d$. at 59-61 (explaining that different value judgments have different implications for answering that question).

141 Cf. Alan D. Morrison, Meta Contracting and Autonomy: A Liberal Theory of the Firm 2 (May 2015) (unpublished draft) (on file with author) (observing that "many people now argue that regulation based solely upon the correction of externalities has been proved to be inadequate").

142 That separate context was examining whether regulation should require firms to mitigate their systemic externalities. See supra notes 76-79 and accompanying text. 
selves, ${ }^{143}$ but also cause much more harm than non-systemic externalities, including widespread poverty and unemployment. ${ }^{144}$ These are exactly the type of externalities that should count in limiting freedom of contract. ${ }^{145}$

Thus, even though the public is not a contracting party, a contractarian model of corporate governance should permit-and arguably should even require-government to limit corporate governance decisions that cause systemic externalities to the public.

\section{The Shareholder-Primacy Model}

A public governance duty technically would be inconsistent with the shareholder-primacy model. This model is not a corporate governance theory per se, but its widespread dominance in the United States ${ }^{146}$ and worldwide $^{147}$ merits attention.

Proponents of shareholder primacy argue that managers of for-profit corporations should govern the firm solely for the best interests of its shareholders. ${ }^{148}$ Although this model is sometimes discussed in a broader context of economic efficiency, it is fundamentally based on agency costs. ${ }^{149}$ Because firms and their agents cannot enter into complete contracts to prevent the latter from shirking, ${ }^{150}$ there should be another way to prevent that. ${ }^{151}$ Shareholders as residual claimants have incentives to monitor the firm's agents. ${ }^{152}$ The agents, in turn, benefit from that monitoring because they

143 Cf. Henry N. Butler \& Jonathan R. Macey, Externalities and the Matching Principle: The Case for Reallocating Environmental Regulatory Authority, 14 YAle L. \& PoL'y Rev. 23, 29 (1996) (leaving open the possibility that government intervention might be justified to prevent externalities that cannot be internalized through Coasian bargaining); Morrison, supra note 141, at 21-23 (observing that firms impose costs on the public that are "not knowingly assumed").

144 See supra notes 76-79 and accompanying text.

145 Schwarcz, supra note 137, at 520-21, 534-36, 551; see also Butler \& Macey, supra note 143, at 29 (arguing, in the environmental context, that government regulation may be appropriate to require a polluter to bear the full costs of its activities when the externality is significant and cannot be bargained away, and the benefits of the regulation outweigh the costs); Morrison, supra note 141, at 22-23 (arguing that when the public is unable to contract to avoid costs imposed by firms, the "regulatory state should minimize" those costs, representing the public as part of a "meta contract").

146 See, e.g., Dodge v. Ford Motor Co., 170 N.W. 668, 684 (Mich. 1919) (explaining shareholder primacy's classical articulation).

147 Cf. Hansmann \& Kraakman, supra note 120, at 443-48 (discussing the ideological convergence on the shareholder-primacy model around the world).

148 Strine \& Walter, supra note 87 , at 346.

149 Agency costs are an aspect of economic efficiency; efficiency increases when agency costs are minimized (because agency costs are a deadweight loss).

150 See Armen A. Alchian \& Harold Demsetz, Production, Information Costs, and Economic Organization, 62 Ам. Econ. Rev. 777 (1972).

151 Stephen M. Bainbridge, Director Primacy: The Means and Ends of Corporate Governance, 97 Nw. U. L. Rev. 547, 566 (2003).

$152 I d$. at 567. 
need focus on only one goal: maximizing shareholder value (usually in the form of stock price). ${ }^{153}$

A public governance duty should nonetheless be consistent with certain assumptions underlying the shareholder-primacy model. Even proponents of shareholder primacy accept that firms can cause externalities, but they believe the efficient response is for government to regulate externalities, as needed, without interfering with corporate governance. ${ }^{154}$ This Article has shown, however, that such regulation may be insufficient to control the excessive corporate risk-taking that causes systemic externalities. ${ }^{155}$ The alternative is to regulate corporate governance. ${ }^{156}$

The analysis has shown that imposing a public governance duty to align the firm's interests with the public's interests in order to control systemic externalities can be reconciled with corporate governance legal theory. I next examine how to implement such a duty without unduly weakening corporate wealth-producing capacity.

\section{B. Implementing a Public Governance Duty}

The discussion below shows that a public governance duty could be feasibly and efficiently implemented. Under a public governance duty, the managers of a systemically important firm ${ }^{157}$ would not only have a private corporate governance duty to investors but also a duty not to engage in excessive risk-taking that could systemically harm the public. ${ }^{158}$ That public duty

153 Lynn A. Stout, Bad and Not-So-Bad Arguments for Shareholder Primacy, 75 S. CAL. L. REv. 1189, 1200 (2002).

154 Cf. generally supra note 87 and accompanying text (discussing the argument that government interference with corporate governance might weaken the wealth-producing capacities of the firm).

155 See supra Section II.B.

156 See supra Section II.C. One can also make other arguments that a public governance duty should not be inconsistent with the shareholder-primacy model, including that such a duty's reduction in systemic cost would exceed any increase in agency costs resulting from the duty. Professor Morrison argues that state intervention-which implicitly would include a public governance duty-would undermine the moral value of the corporate form, which allows "choices that individuals, left to themselves, might prefer to make." Morrison, supra note 141, at 4 . I would argue to the contrary, that individuals should have no moral right to cause systemic harm to others.

157 Recall that a public governance duty should apply only to managers of systemically important firms, which in this Article are limited to financial firms that are systemically important. See supra note 5 and the introduction to Section III.A.

158 Cf. John Carney, Big-Bank Board Game Puts Shareholders in Second Place, Wall St. J. (Apr. 5, 2015), http://www.wsj.com/articles/big-bank-board-game-puts-shareholders-insecond-place-heard-on-the-street-1428255363 (noting a speech by U.S. Federal Reserve Governor Daniel Tarullo suggesting that "corporate governance would need to change to broaden the scope of boards' fiduciary duties to reflect macroprudential [i.e., systemic] regulatory objectives"). The nation of Iceland has actually enacted legislation that appears to require, at least in principle, the managers of at least certain systemically important firms to "operate[ ] [their firms] . . . in the interests of . . shareholders . . . and the entire economy." Act on Financial Undertakings (Act No. 161/2002) (Ice.), https://eng.atvinnu 
raises at least six practical questions: (1) How should a public governance duty be legally imposed? (2) How should managers assess the public costs and private benefits of a risk-taking activity? (3) How should managers balance those costs and benefits when deciding whether the firm should engage in a given risk-taking activity? (4) How should a public governance duty be enforced? (5) Weighing the goals of protecting the public against systemic externalities and encouraging the best people to serve as managers, to what extent should managers performing their public governance duty have the protection of a business judgment rule as a defense to liability? (6) To what extent should managers be protected under directors and officers (D\&O) liability insurance? Consider these questions in turn.

\section{Legally Imposing the Duty}

A public governance duty could be legally imposed in different ways. Courts, for example, could create such a duty through judicial decisions. Or legislatures could amend their corporation laws to require such a duty.

Because this Article is primarily normative, its emphasis is on whether the duty should be imposed, not how it might be imposed. Nonetheless, the following observations may be relevant to that latter inquiry. As at least one commentator has observed, changes in corporate governance law that could have "profound public policy" implications that "ultimately shape the fabric of the form of capitalism that a society embraces" should be undertaken by "our legislatures," which are "designed to allow for a full airing of social and political currents." 159

In the United States, this would mean that a public governance duty should be imposed either by state legislatures (especially the Delaware legislature, because most domestic firms are incorporated under Delaware law) or by the U.S. Congress ("Congress"). Because corporation law in the United States is traditionally state, not federal, states ideally should take the lead in imposing such a duty. By analogy, states are already beginning to allow corporate managers to consider non-shareholder constituencies, such as "employees, suppliers, customers and creditors of the corporation, and . . . communities." 160

It is questionable, however, whether state legislatures are well-positioned to impose a public governance duty. They are unlikely to want to impose such a duty because it could discourage firms from incorporating in their

vegaraduneyti.is/laws-and-regulations $/ \mathrm{nr} / \mathrm{nr} / 7366$ (unofficial English translation provided by Icelandic government). The Dean of the University of Iceland's law faculty believes this law "puts clear constraints on the directors and managers" of those firms and "underlines the difference between" those firms "and other companies that usually have the only purpose of increasing shareholder value." E-mail from Eyvindur G. Gunnarsson, Dean, Faculty of Law, Univ. of Ice., to author (Feb. 14, 2015) (on file with author).

159 Yalden, supra note 133 , at 410.

16015 Pa. Stat. and Cons. Stat. Ann. § 1715(a)(1) (West 2016). 
states. ${ }^{161}$ Furthermore, systemic risk is a national and international problem, not usually a local state problem. ${ }^{162}$ The "internalization principle" recognizes that regulatory responsibilities should generally be assigned to the unit of government that best internalizes the full costs of the underlying regulated activity. ${ }^{163}$ For these reasons, Congress may be best situated to impose a public governance duty, ${ }^{164}$ and indeed the Sarbanes-Oxley Act and the DoddFrank Act set legislative precedents for Congress limiting state corporation law. ${ }^{165}$ A federal law public governance duty would also override inconsistent state corporation law. ${ }^{166}$

Congress might already implicitly have granted power to the Federal Reserve to create a public governance duty. Section 165(h) of the DoddFrank Act directs the Federal Reserve Board to require each publicly traded nonbank financial company supervised by the Board and each publicly traded bank holding company with total consolidated assets of $\$ 10$ billion or more to establish a risk committee, which will be responsible for overseeing

161 Armour \& Gordon, supra note 37, at 75 (observing that "systemically important firms might be expected to incorporate away from jurisdictions adopting a [director] liability rule").

162 In the corporate governance context, this disconnect is potentially even greater because firms operating anywhere in the United States can select another state's law under which to incorporate, and that law will control the firm's governance. Therefore, a state's corporate governance law need not even take that state's risks into account.

163 Robert D. Cooter \& Neil S. Siegel, Collective Action Federalism: A General Theory of Article I, Section 8, 63 Stan. L. Rev. 115, 137 (2010); see also Enhanced Prudential Standards for Bank Holding Companies and Foreign Banking Organizations, 79 Fed. Reg. 17,240, 17,249 (Mar. 14, 2014); Clayton P. Gillette, Who Should Authorize a Commuter Tax?, 77 U. CHI. L. Rev. 223, 233 (2010). The internalization principle's rationale is that government entities will have optimal incentives to take into account the full costs and benefits of their regulatory decisions only if the impacts of those decisions are felt entirely within their jurisdictions. Wallace E. Oates, Fiscal Federalism 46-47 (1972).

164 Cf. Armour \& Gordon, supra note 37, at 68 (proposing that implementing director liability for systemic harm could require "a Federal liability regime"). Professors Armour and Gordon also suggest that "the mere possibility of federal intervention could itself spur Delaware" to impose something akin to a public governance duty, because "the most powerful driver of innovation in Delaware corporate law has . . . been . . . the threat of federal pre-emption." Id. at 75 .

165 Hillary A. Sale, Public Governance, 81 Geo. WASH. L. Rev. 1012, 1014 (2013) (discussing those Acts as federal legislative precedents in which Congress limited how state corporation law enabled corporate private ordering). For example, Sarbanes-Oxley requires a public company's audit committee members to be independent and makes specific managers individually responsible for the accuracy of financial reports. Id. at 1021. Dodd-Frank requires the directors on the compensation committee to be independent and also, through its "say-on-pay" provisions, requires precatory shareholder approval of the substantive terms of executive compensation. Id. at 1027-29.

166 See infra note 170. For example, a federal law public governance duty would override a disclaimer of liability for gross negligence included in a firm's certificate of incorporation under Delaware General Corporation Law. See Del. Code. Ann. § 102(b) (7) (West 2015). 
the company's risk management practices. ${ }^{167}$ The Board's implementing regulations currently only require risk committees to focus on risks to the firm, not to the public. ${ }^{168}$ That microprudential focus subjects risk committees to the same misalignment discussed earlier. ${ }^{169}$ As a result, members of a risk committee who vote to favor the public over investor interests may even be violating their state law corporate governance duties. However, assuming Congress's mandate to the Board is broad enough, the Board could issue additional regulations that require risk committees to also consider systemic risks to the public. ${ }^{170}$

16712 U.S.C. $\$ 5365$ (h) (2012) (stating that the risk committee should be responsible for overseeing the firm's enterprise-wide risk management practices-i.e., overseeing the broad spectrum of risks facing the firm and the firm's affiliated group). The risk committee is also required to have independent directors (as the Federal Reserve Board deems appropriate), including at least one risk management expert having experience in identifying, assessing, and managing risk exposures of large, complex firms. Id. For further discussion of risk committees, see Kristin N. Johnson \& Steven A. Ramirez, New Guiding Principles: Macroprudential Solutions to Risk Management Oversight and Systemic Risk Concerns, 11 U. ST. Thomas L.J. 386, 416-18 (2014).

168 The Federal Reserve Board's regulations do not require risk committees to take systemic risk into account. See 12 C.F.R. \$ 252.20-22, 30-35 (2015) (at most indirectly suggesting that possibility by requiring that the level of risk management expertise possessed by the risk committee of a company should rise in accordance with a company's rising threat of systemic risk to the economy). Risk committees formed pursuant to the Board's regulations likewise do not appear to take systemic risk into account. See, e.g., Maureen P. Errity \& Henry J. Ristuccia, Deloitte, Risk Committee Resource Guide for BOARDS app. A at 18-20 (2012) (stating in its "[s]ample board risk committee charter" that the risk committee's purpose is to identify and assess "the risks that the organization faces" and to "[p]rovide input to management regarding the enterprise's risk appetite and tolerance"); Matteo Tonello, Should Your Board Have a Separate Risk Committee?, Harv. L. Sch. F. ON Corp. Governance \& Fin. Reg. (Feb. 12, 2012), http://corpgov.law.harvard.edu/2012/ $02 / 12$ /should-your-board-have-a-separate-risk-committee/ (stating that the risk committee's function is to "develop a mutual understanding regarding the risks the company faces over time as it executes its business model for creating enterprise value").

169 See supra notes 8-12 and accompanying text. Although that microprudential focus reduces the likelihood that individual firms will fail, that at most partially reduces systemic risk. See supra note 15 .

170 During an October 19, 2015, presentation on "Regulating Systemic Risk in Insurance," I suggested to the U.S. Federal Reserve Board and Reserve Bank staff that they should consider requiring risk committees to also consider systemic risks to the public. If the delegation of authority under section 165(h) of the Dodd-Frank Act is broad enough, the Board's regulations requiring a public governance duty should override contrary state law by virtue of the Supremacy Clause of the U.S. Constitution. Cf. Peter O. Mülbert \& Alexander Wilhelm, CRD IV Framework for Banks' Corporate Governance, in European BANKING UnION 155, 197 (Danny Busch \& Guido Ferrarini eds., 2015) (stating that the new European Capital Requirements Directive (CRD) IV "requires the decisions of . . . the management body ... to take into account not only the interests of shareholders, but also ... the public interest"). 


\section{Assessing Costs and Benefits}

How should managers of a systemically important firm, or members of such a firm's risk committee, ${ }^{171}$ assess the public costs and private benefits of a risk-taking activity? Although a range of approaches is possible, this Article offers two examples of approaches: one subjective and the other more objective and ministerial. On a case-by-case basis, managers could choose which approach to follow.

When deciding how to vote on matters as to which they believe there could be significant systemic costs to the public, managers following a subjective approach would simply consider those costs and balance them against benefits-the same way they would consider any other relevant costs and benefits when making a corporate governance decision. Their assessment and balancing might, but would not necessarily, be documented or explained. ${ }^{172}$ Managers may favor this approach because it would not change their current behavior.

This subjective approach would be subject to at least three drawbacks, however. ${ }^{173}$ First, because the consequences of a systemic collapse can be devastating to the public, the decisionmaking process to mitigate that harm should be more transparent. ${ }^{174}$ Second, managers following a subjective approach may be subject to peer pressure to favor investor profitability over avoiding public harm. ${ }^{175}$ Third, although courts generally try to avoid second-guessing management decisions, ${ }^{176}$ even managers should want to follow an approach that provides an explicit safe harbor against litigation-at least if the approach is relatively ministerial.

171 See supra notes 167-70 and accompanying text (discussing risk committees). Professors Armour and Gordon also advocate "board-level review of risk-taking that may give rise to systemic harms, effectuated through a risk-committee process." Armour \& Gordon, supra note 37, at 64. Even if the cost-benefit assessment is performed by members of a firm's risk committee, the firm's senior managers (e.g., members of its board of directors) "should retain overall responsibility for risk oversight, mirroring [their] overall responsibility for strategy." Tonello, supra note 168.

172 Cf. James D. Cox \& Thomas Lee Hazen, Corporations 191 (2d ed. 2003) (observing that "what is required for the board to act reasonably to inform itself varies with the facts").

173 The more objective approach also could have drawbacks, such as its simplifying assumption that the only way a risky project could cause systemic costs is if the project's being unsuccessful causes the firm to fail. See infra note 178.

174 Cf. infra notes 189-93 (arguing that the harmful consequences of a systemic collapse justify the application of a precautionary principle).

175 As a director of special purpose entities, I routinely experienced this peer pressure. I also saw this type of peer pressure routinely exercised against the senior manager of a banking client's internal risk committee, to greatly favor profitability over caution. To attempt to mitigate this pressure, a firm's risk committee ideally should have at least two independent members.

176 See infra notes 206-10 and accompanying text (discussing the business judgment rule as a defense to liability). 
Consider how to craft a possible ministerial safe-harbor objective approach, using the generic example of a systemically important firm engaging in a risky project that could be profitable. The expected private benefits can be calculated as the expected value of the project to the firm's investors (usually the shareholders), which I'll call ":

" (expected value of project to investors $)=$

[X\% chance of project being successful $\times \$ Y$ value to investors from that success $\left.^{177}\right]-[(1-\mathrm{X} \%$ chance of project being unsuccessful $) \times \$ W$ loss from that failure]

The expected public costs can be calculated as the expected value of the project's systemic costs, which I'll call \$:

$\$($ expected value of project's systemic costs $)=$

( 1 - X\% chance of project being unsuccessful) $\times \mathrm{F} \%$ chance of firm failing as a result of the project being unsuccessful $\times \$ Z$ resulting systemic costs. ${ }^{178}$

What values should management use? Most of these values would be pure business judgments about which the firm's managers should have sufficient information, or at least much more information than third parties. For example, those managers should have much more information than third parties about valuing $\mathrm{X} \%$, the chance of the project being successful; $\$ \mathrm{Y}$, the value to investors from that success; $\$ \mathrm{~W}$, the loss from the project's failure; and $\mathrm{F} \%$, the chance of the firm failing as a result of the project's failure (i.e., effectively as a result of the $\$ \mathrm{~W}$ loss).

The exception, however, is the value for $\$ \mathrm{Z}$, the systemic costs if the firm fails. Government financial regulators are likely to know much more about valuing $\$ \mathrm{Z}$ than the firm's managers. That valuation should therefore be a public policy choice.

As a policy matter, there are several possible ways of valuing $\$ Z$. One approach would be to assume that the firm actually fails, with a systemically negative impact to the real economy. That would yield an indeterminate but

$177 \$ Y$, the value to investors from the project's success, could be measured by profit or whatever other metric the firm normally uses.

178 This equation has been simplified in two ways. First, it assumes that the only way a risky project could cause systemic costs is if the firm fails as a result of the project's being unsuccessful. Thus, managers would only need to engage in the assessment when deciding on a risky project whose failure could, either itself or in combination with other factors of which such managers are or should be aware, cause the firm to fail. This approach may miss other triggers of systemic risk, such as the negative effects of correlated portfolios. Cf. Schwarcz \& Schwarcz, supra note 63, at 1595-97 (discussing the systemic impact of correlated investments by insurance companies). Second, the full equation would be [( $1-\mathrm{X} \%$ chance of project being unsuccessful) $\times \mathrm{F} \%$ chance of firm failing as a result of the project being unsuccessful $\times \$ Z$ resulting systemic costs $]+[(\mathrm{X} \%$ chance of project being successful $\times \mathrm{A} \%$ chance of firm failing as a result of the project being successful $\times \$ \mathrm{~B}$ resulting systemic costs]. However, A\%, the chance of the firm failing as a result of the project being successful, is likely to be zero. 
potentially huge number for $\$ Z$ Z. ${ }^{179}$ But that valuation approach could be misleading for at least two reasons. First, the failure of any given firm, no matter how large, would be unlikely by itself to be the sole cause of a major financial crisis; even Lehman Brothers' failure did not, by itself, cause the financial crisis. ${ }^{180}$ Second, at least in the United States, the "living will" requirement under the Dodd-Frank Act is intended to minimize the systemic consequences of any given systemically important firm's failure. ${ }^{181}$

A more plausible way to value $\$ \mathrm{Z}$ would be to estimate the costs of the firm's failure to its immediate counterparties. The rationale for this approach is that first-order systemic consequences are more likely to result from a systemically important firm's failure than a full-blown financial collapse. ${ }^{182}$ Such a cost estimate was done by analysts at J.P. Morgan for the possible failure of Long-Term Capital Management (LTCM), a large hedge fund whose losses in the Russian bond market brought it close to default; they found that LTCM's failure would have cost its larger bank-creditors \$500-700 million each. ${ }^{183}$

Another plausible approach to valuing $\$ \mathrm{Z}$ would be to base its value on the estimated cost of a government bailout to avoid a systemic failure. Such an estimate could be required to be made by the government, for example, ${ }^{184}$ as part of the process of designating a firm as a "systemically important financial institution" (SIFI), ${ }^{185}$ and thereafter periodically updated by the government.

179 Estimates of the cost of the financial crisis are in the trillions. See, e.g., Tyler Atkinson et al., How Bad Was It? The Costs and Consequences of the 2007-09 Financial Crisis, Fed. Res. Bank Dall. Staff Papers, July 20, 2013, at 1 (estimating the likely cost of the financial crisis to the United States as "greater than the value of one year's output," or greater than $\$ 15.5$ trillion).

180 The shock caused by the Federal Reserve's failure to bail out Lehman Brothers was merely the final straw that triggered the collapse that led to the financial crisis. See The Origins of the Financial Crisis: Crash Course, supra note 3.

181 See supra note 49 and accompanying text.

182 The Dodd-Frank Act attempts to minimize systemic disruptions in the event of a failed systemically important financial institution.

183 Roger Lowenstein, When Genius Failed: The Rise and Fall of Long-Term Capital Management 190 (2000).

184 The process by which the government should make and periodically update such an estimate is beyond this Article's scope. One way it might do so, however, is by attempting to match the firm in question to the most "comparable company" that has received bailout money in the past, based on its tracking of data for bailout recipients in connection with the financial crisis. See, e.g., Bailout Recipients, ProPublicA, http://projects.propublica .org/bailout/list/index (last updated Oct. 17, 2016) (providing a bailout list, which tracks every dollar and every recipient of federal government bailout money). Of course, no estimate would be perfect. Cf. Aswath Damodaran, Applied Corporate Finance 565 (4th ed. 2015) (observing that a comparable companies approach is never based on exactly comparable companies).

185 Such an estimate should, ideally, take into account both domestic and foreign bailout costs. If the United States is designating a global firm as a SIFI, the bailout cost would include not only the United States bailout cost but also the costs of any necessary foreign bailouts. 


\section{Balancing Costs and Benefits}

Next consider how managers should balance public costs and private benefits when deciding whether their firm should engage in a given risktaking activity. Managers following a subjective approach would simply balance those costs and benefits the same way they would balance any other relevant costs and benefits when making a corporate governance decision. ${ }^{186}$ But that subjective approach would again be subject to the drawbacks that the balancing process should be more transparent, that managers engaging in subjective balancing may be subject to peer pressure to assign more weight to investor profitability than to avoiding public harm, and that subjective balancing does not provide a clear safe harbor against litigation.

Managers following the ministerial safe harbor objective approach to assessing public costs and private benefits could also use that approach to balance those costs and benefits. Using the earlier terminology, they would be balancing " (the expected value of the project to the firm's investors) against \$ (the expected value of the project's systemic costs), recognizing that a firm's wealth production to society should be assessed net of potential systemic costs. Such a balancing would be needed only when deciding on a risky project whose failure could, either itself or in combination with other factors of which such managers are or should be aware, cause the firm to fail. ${ }^{187}$ Managers should be aware of such projects. ${ }^{188}$

To ensure that the balancing does not unduly weaken corporate wealthproducing capacity, it should be designed to yield an economically efficient result. From a strict economic efficiency standpoint, the project would be Kaldor-Hicks efficient if " exceeds $\$ .{ }^{189}$ As a public policy matter, however, simple Kaldor-Hicks efficiency may be insufficient because the magnitude and harmful consequences of a systemic collapse, if it occurs, could be devastating. When balancing the costs and benefits of activities that might pose

\section{See supra note 172 and accompanying text.}

187 See supra note 178 and accompanying text. Managers making this determination and the other determinations contemplated by a public governance duty would be protected, of course, by the business judgment rule. See infra notes 206-25 and accompanying text.

188 Armour \& Gordon, supra note 37, at 69 (observing that "it is surely the board's responsibility to identify those risks which are of a magnitude and kind as to threaten the firm's stability").

189 Kaldor-Hicks efficiency is the practical standard used by economists. RoBIN PAUL Malloy, Law in a Market Context: An Introduction to Market Concepts in Legal REASONING 190 (2004). A project is Kaldor-Hicks efficient if its overall benefits exceed its overall costs, regardless of who bears the costs and who gets the benefits. Id. Kaldor-Hicks efficiency implicitly assumes that the distribution of benefits and costs is not controlled by the party-in our case, a firm's managers-also controlling the decision whether to engage in the project. Id. at 190-91. But those managers do not completely control the distribution of benefits; the public usually benefits, at least indirectly, from corporate risk-taking that benefits investors. 
great harm, policymakers normally apply a precautionary principle. ${ }^{190}$ "The strongest form of the precautionary principle" - under which "the potential for great harm justifies any regulatory intervention, and/or that the proponent of an activity must conclusively demonstrate that the activity is safe before it is allowed"191_ should not, however, apply to corporate decisionmaking because it could stymie much reasonable risk-taking, thereby weakening corporate wealth-producing capacity.

It may be more appropriate to apply a weaker form of the precautionary principle, which would merely require "a margin of safety" to demonstrate that a given risk-taking activity is justified. ${ }^{192}$ Under this weaker form of the precautionary principle, engaging in a project for which " considerably exceeds \$ should not constitute excessive risk-taking. ${ }^{193}$ This formulation would not completely prevent risk-taking that causes systemic externalities. It should, however, reduce that risk-taking by including systemic externalities in the corporate governance balancing, thereby also shaping corporate governance norms to begin to take the public into account. ${ }^{194}$

In examining how to apply this approach, assume for illustrative pur$\operatorname{poses}^{195}$ that a systemically important firm's bailout cost ( $\$ \mathrm{Z}$ ) would be $\$ 500$ million and that the firm's managers estimate the other values as follows:

$\mathrm{X} \%$ (the chance of the project being successful) $=80 \%$.

$\$ Y$ (the value to investors from that success) $=\$ 50$ million.

190 Hilary J. Allen, A New Philosophy for Financial Stability Regulation, 45 Loy. U. CHI. L.J. 173, 191 (2013) (observing that precautionary principles generally direct "regulators to err on the side of regulating an activity when the outcome of that activity is uncertain, but potentially irreversible and catastrophic"). Although precautionary principles have been mostly applied in assessing environmental regulation, they also can have application to financial regulation. Id. at 191-92; see also James Salzman \& Barton H. Thompson, Jr., Environmental Law and Policy 16 (2d ed. 2007); Saule T. Omarova, License to Deal: Mandatory Approval of Complex Financial Products, 90 WAsh. U. L. Rev. 63, 84 (2012) ("[A]dopting and operationalizing the general concept of precaution in the context of postcrisis financial systemic risk regulation may be a worthwhile, and even necessary, exercise."); Schwarcz, supra note 7, at 234-35 (applying a precautionary principle to cost-benefit balancing involving systemic risk).

191 Allen, supra note 190, at 195.

192 See Cass R. Sunstein, Beyond the Precautionary Principle, 151 U. PA. L. REv. 1003, 1014 (2003) (discussing this form of the precautionary principle, under which "[r] egulation should include a margin of safety, limiting activities below the level at which adverse effects have not been found or predicted").

193 The margin of safety, in other words, is that " does not merely exceed but considerably exceeds $\$$. To provide more of a safe harbor for managers, the regulatory language of the public governance duty could specify a percentage that is deemed to provide that margin.

194 Cf. Lee, supra note 81, at 124 (observing that "provisions embedded within corporate [governance] law might influence the managers' conception of their role, with the result that the norms underlying such provisions are capable of guiding managers even within the gaps left by legal enforcement mechanisms").

195 These values are solely illustrative. They rely on no hard empirical data, and a quantitative analysis is no better than its assumptions. 
$\$ \mathrm{~W}$ (the loss from the project's failure) $=\$ 20$ million.

F\% (the chance of the firm failing as a result of the project's failure) $=10 \%$.

Applying these values yields the following:

" (expected value of the project to the firm's investors)

$=[(80 \%$ chance of project being successful $) \times \$ 50$ million value to investors from that success] - [ $(20 \%$ chance of project being unsuccessful) $\times \$ 20$ million loss from that failure]

$=\$ 36$ million

\$ (expected value of the project's systemic costs)

$=(20 \%$ chance of project being unsuccessful $) \times 10 \%$ chance of firm failing as a result of the project being unsuccessful $\times \$ 500$ million resulting systemic costs

$=\$ 10$ million

If these values are realistic, " (\$36 million) would considerably outweigh $\$$ (\$10 million). Managers of a systemically important firm that undertake this project would not be engaging in excessive risk-taking.

Much will depend on valuing $\$ \mathrm{Z}$, the systemic costs if the firm fails. If $\$ \mathrm{Z}$ were $\$ 1.5$ billion, rather than $\$ 500$ million, the expected value of the project's systemic costs would equal $\$ 30$ million. Managers of a systemically important firm that undertake the project might then be engaging in excessive risk-taking because " (\$36 million) would not considerably outweigh \$ (\$30 million).

Because this balancing includes a margin of safety against systemic risk, it could reduce a firm's wealth production from a given project that is not undertaken. Nonetheless, the net overall wealth production to society, after subtracting systemic costs, should be increased. ${ }^{196}$

\section{Enforcing a Public Governance Duty}

Who should enforce a public governance duty? Under existing corporate governance law, shareholder derivative suits are the primary enforce-

196 The balancing also should satisfy what at least one leading civil law scholar characterizes as the burden that should be met in order for financial regulation to favor general welfare over corporate governance autonomy. See Matthias Haentjens, Party Autonomy, Public Policy and European Bank Insolvency Law, (Hazelhoff Centre for Fin. Law, Research Paper Series No. 7, 2015). In connection with examining bank crisis management measures under the Dutch Intervention Act, Professor Haentjens observes that private autonomy is a "fundamental principle" of European Union law. Id. at 9. Nonetheless, he argues that "public welfare may take priority over party autonomy" if the regulation protecting public welfare (1) unequivocally serves the public welfare, (2) proportionately and optimally balances public welfare against party autonomy, and (3) explicitly states that it is applying the balancing. Id. at 11-12. This Article's public governance duty should meet all of these conditions. 
ment mechanism. Shareholders would have no interest, however, in suing managers of their firm for externalizing systemic harm. Therefore, the government, by default, at least should have the right to enforce the public duty.

The government, however, may be unable to effectively monitor a firm's internal compliance with the public governance duty until the firm fails, when systemic consequences may be irremediable. To facilitate better monitoring, regulation implementing a public governance duty should include whistleblower incentives, ${ }^{197}$ including anti-retaliation protection for managers or others involved in the risk assessment who inform government officials of their firm's noncompliance ${ }^{198}$ and possibly also monetary rewards. ${ }^{199}$ Regulation implementing a public governance duty might even impose an obligation on managers involved in the risk assessment to inform government officials of their firm's noncompliance. ${ }^{200}$

Another way to facilitate better monitoring, and more specifically enforcement, of the public governance duty would be to incentivize members of the public themselves. Qui tam suits under the False Claims Act, ${ }^{201}$ the primary litigation tool for combating fraud against the United States government, constitute a strong precedent for this. That Act permits private citizens to sue alleged defrauders in the name of the government. ${ }^{202}$ If the

197 The Sarbanes-Oxley Act (SOX) and the Dodd-Frank Act already protect whistleblowers in the financial industry to some extent, including providing for anti-retaliation provisions.

198 Informing government officials of one's firm's noncompliance is called external reporting. In principle, whistleblowers who engage in internal reporting-informing someone within the firm, such as an employment supervisor-should also be protected. Cf. Orly Lobel, Linking Prevention, Detection, and Whistleblowing: Principles for Designing Effective Reporting Systems, 54 S. Tex. L. Rev. 37, 41 (2012) (“[A]n important principle for designing reporting systems is that, under most circumstances, attempts to resolve compliance issues should first be made internally. Only if internal reporting fails or is deemed impractical should external reporting to an administrative agency or another outside authority be encouraged."). Managers involved in the risk assessment associated with the public governance duty, however, will already be the most senior managers. See supra text accompanying note 8 .

199 The Dodd-Frank Act, for example, offers monetary incentives to whistleblowers and allows them to commence actions in federal court without first seeking administrative relief. See 15 U.S.C. $\$ 78 u-6$ (b) (2012); id. § 78u-6(h) (1)(B). A whistleblower who prevails in court may receive up to twice the amount of wages lost due to retaliation, as well as attorneys' fees and ten percent to thirty percent of any cash recovered by the SEC based on the whistleblower report. See id. $\S 78 \mathrm{u}-6(\mathrm{~b})$.

200 Managers complying with this obligation should logically receive anti-retaliation protection. However, in some statutes, such as the Whistleblower Protection Act, a manager who reports wrongdoing as part of his "duty" may be excluded from anti-retaliation protections if the reporting is made in the ordinary course of the manager's duties. See Yuval Feldman \& Orly Lobel, The Incentives Matrix: The Comparative Effectiveness of Rewards, Liabilities, Duties, and Protections for Reporting Illegality, 88 Tex. L. Rev. 1151, 1167 (2010).

20131 U.S.C. $\$ \$ 3729-33$ (2012).

202 Id. $§ 1330(\mathrm{c})(3)$. 
suit is successful or settled, the citizen-plaintiff is entitled to thirty percent of the award or settlement, plus costs and attorneys' fees. ${ }^{203}$

Qui tam lawsuits raise a standing question; the citizen-plaintiff "suffers no injury" and thus would appear to "lack the 'injury in fact' required to create Article III standing" under the United States Constitution. ${ }^{204}$ Nonetheless, the Supreme Court has found standing through a somewhat circular argument-that the Act's partial assignment of the government's claim to the citizen-plaintiff provides a sufficient stake in the outcome to create Article III standing. ${ }^{205}$

That same circular argument could justify citizen standing to sue to impose personal liability on managers who breach their public governance duty, if those citizen-plaintiffs were entitled to a percentage of the award or settlement. Moreover, those citizen-plaintiffs would have an additional standing claim: as members of the public, they would be directly harmed by a systemically important firm's collapse.

Assuming that regulation implementing a public governance duty allows qui tam lawsuits, regulators should provide for an ongoing study of those lawsuits to ensure they do not overwhelm the courts or discourage good people from serving as managers.

\section{Business Judgment Rule as a Defense}

A critical question concerns the business judgment rule as a defense to liability. In the traditional corporate governance context, managerial decisions-including risk-taking decisions-are protected to some extent by this rule, which presumes that managers should not be personally liable for harm caused by negligent decisions made in good faith and without conflicts of interest-and in some articulations of the business judgment rule, also without gross negligence. ${ }^{206}$ Weighing the goals of protecting the public against systemic externalities and encouraging the best people to serve as managers, to what extent should managers performing their public governance duty have the protection of that rule?

One of the business judgment rule's primary justifications ${ }^{207}$ is an attempt to balance somewhat similar goals: protecting investors against

203 David Freeman Engstrom, Private Enforcement's Pathways: Lessons from Qui Tam Litigation, 114 Colum. L. Rev. 1913, 1944 (2014).

204 Richard A. Bales, A Constitutional Defense of Qui Tam, 2001 Wis. L. REv. 381, 384 (footnote omitted).

205 Id. (citing Vt. Agency of Nat. Res. v. United States ex rel. Stevens, 529 U.S. 765, 777-78 (2000)).

206 Christine Hurt, The Duty to Manage Risk, 39 J. Corp. L. 253, 258 (2014). But cf. In re Walt Disney Co. Derivative Litig., 906 A.2d 27, 65 (Del. 2006) (stating that "grossly negligent conduct, without more, does not and cannot constitute a breach of the fiduciary duty to act in good faith").

207 The business judgment rule's other primary justification is that the exercise of managerial business judgment is inappropriate for court review. Hurt, supra note 206, at 
losses, and encouraging the best managers to serve. ${ }^{208}$ Even though the business judgment rule can reduce investor protection, that reduction is seen as a necessary cost. Because managers cannot always precisely predict the consequences of their corporate governance decisions, some decisions that appear correct when made can result in investor harm. Without the business judgment rule's protection, competent managers would be exposed to liability, ${ }^{209}$ discouraging the quality of people who will consider serving as managers. ${ }^{210}$

In a public-governance-duty context, consider how to balance the parallel goals of protecting the public against systemic externalities and encouraging the best managers to serve. The first goal, protecting the public against systemic externalities, should be more important than protecting investors against losses because systemic harm can be widespread and devastating. ${ }^{211}$ The second goal, encouraging the best managers to serve, should also be more important; managers may find it even more difficult to precisely predict the public governance consequences of their decisions because it is harder to predict systemic than ordinary consequences ${ }^{212}$ and also harder to predict consequences to the public than to the firm and its investors. ${ }^{213}$ Managers therefore may need more encouragement to serve.

Because there would be increased importance for each of these competing goals in a public-governance-duty context, the business judgment rule

259-60. This justification should be as applicable in a public-governance-duty context as in a traditional corporate governance context.

208 See, e.g., Ryan Scarborough \& Richard Olderman, Why Does the FDIC Sue Bank Officers? Exploring the Boundaries of the Business Judgment Rule in the Wake of the Great Recession, 20 Fordham J. Corp. \& Fin. L. 367, 377 (2015) (explaining that a typical justification for business judgment rule protection is fear that qualified individuals will refrain from serving as managers due to the significant liability exposure).

209 Cf. Melvin Aron Eisenberg \& James D. Cox, Business Organizations: Cases and Materials, 625-26 (unabr. 11th ed. 2014) (explaining that due to hindsight bias, people often erroneously treat decisions that have bad results as bad decisions).

210 Cf. William T. Allen, Jack B. Jacobs \& Leo E. Strine, Jr., Realigning the Standard of Review of Director Due Care with Delaware Public Policy: A Critique of Van Gorkom and Its Progeny as a Standard of Review Problem, 96 Nw. U. L. Rev. 449, 455 (2002) (explaining the highly disproportionate incentives: liability for an imprudent decision could be in the millions, whereas outside directors rarely receive fees commensurate with that level of risk); Scarborough \& Olderman, supra note 208, at 377 (arguing that even management salaries pale compared to the huge potential liability managers face after a crisis). A related justification is that the business judgment rule encourages appropriate levels of risk-taking. Id. at 378-79. Without that rule's protections, managers may be unduly risk-averse, thereby avoiding risky but socially desirable economic projects. Allen, Jacobs \& Strine, supra, at 455 .

211 See supra note 15 and accompanying text (observing that systemic externalities damage the economy and harm the public); supra note 179 (estimating the likely cost of the financial crisis in the trillions). Also, members of the public, unlike investors, cannot mitigate their harm by voting to replace managers or selling securities.

212 Cf. Anabtawi \& Schwarcz, supra note 40, at 93-96 (observing, among other things, that we do not yet know enough about systemic shocks to prevent their transmission).

213 Cf. Friedman, supra note 87 (arguing that managers are experts in running the company, not experts in improving social welfare). 
should still be needed to help balance those goals. ${ }^{214}$ The next question is whether the business judgment rule should therefore apply to performance of a public governance duty the same way it applies to performance of traditional corporate governance duties.

At least in a traditional corporate governance context-in which the first competing goal is protecting investors against losses, not protecting the public against systemic harm-scholars have rejected arguments to weaken the business judgment rule for managers who engage their firms in excessive risk-taking. A weaker rule, they argue, would require courts to exercise inappropriate discretion, and it should be up to shareholders to evaluate corporate risk through their investment decisions, not through litigation. ${ }^{215}$ In a public-governance-duty context, courts likewise should not be required to exercise inappropriate discretion. However, the argument that it should be up to shareholders to evaluate corporate risk through their investment decisions would be inapplicable because systemic externalities primarily affect the public, not shareholders. ${ }^{216}$

Applying these scholars' arguments to a public-governance-duty context, it should be acceptable to weaken the business judgment rule for managers who engage their firms in excessive systemic risk-taking if that weakening would not require courts to exercise inappropriate discretion or discourage the best people from serving. Scholars who have examined corporate governance from the standpoint of systemic harm likewise argue that "the case for business judgment protection" is weaker. ${ }^{217}$ This Article next argues that the public interest should in principle require a modest weakening of the business judgment rule, if such weakening would not require courts to exercise inappropriate discretion or discourage the best people from serving. It then proposes how, consistent with those goals, the business judgment rule should be weakened, and also shows why the proposed weakening would be consistent with the business judgment rule's actual application in at least some states, including Delaware.

The public interest should require a modest weakening of the business judgment rule because public harm breaches one of the basic assumptions of that rule's application-that there be no conflict of interest. ${ }^{218}$ The interest of a manager who holds significant shares or interests in shares, or whose compensation or retention is dependent on share price, is aligned with the

214 Recall that the business judgment rule's other primary justification should be as applicable in a public-governance-duty context as in a traditional corporate governance context. See supra note 207.

215 See Hurt, supra note 206, at 259-60; Robert T. Miller, Oversight Liability for RiskManagement Failures at Financial Firms, 84 S. CAL. L. Rev. 47, 120-21 (2010).

216 Recall that shareholders generally want their firms to take potentially profitable risks, regardless of the possible systemic impact. See supra note 6 and accompanying text. 217 Armour \& Gordon, supra note 37, at 39. They make this argument on the basis that "diversified shareholders [then] want managers to take less risk." Id. Professors Armour and Gordon also observe that "[d]irector liability is not an innovation in the control of risk-taking by financial institutions." Id. at 62 .

218 See supra note 206 and accompanying text. 
firm's shareholders, not with that of the public. To that extent, the manager would have a conflict of interest. ${ }^{219}$ Most managers are conflicted in that way; they should not be given quite the same absolute deference that the business judgment rule gives non-conflicted managers.

So how should the business judgment rule be weakened without requiring courts to exercise inappropriate discretion or discouraging the best people from serving as managers? One solution would be to prevent conflicted managers who are grossly negligent - that is, who fail to use even slight care in assessing systemic harm to the public-from using the rule as a defense. Technically, this solution does not even change the business judgment rule; it merely applies the gross negligence standard that is articulated as part of that rule, though rarely utilized with any rigor. ${ }^{220}$ Moreover, because courts routinely review whether other types of actions are grossly negligent, they should not find it "inappropriate" or impractical to review corporate risktaking actions under a gross negligence standard. As a practical matter, furthermore, managers who follow a reasonable procedure to balance public costs and private benefits-such as the procedure discussed in this Article ${ }^{221}$ - should be protected. ${ }^{222}$ That would effectively conform the business judgment rule's public-governance-duty application to a duty of process care, the standard commonly used in the United States. ${ }^{223}$

The requirement that managers use at least slight care in assessing systemic harm to the public would also be consistent with the business judgment rule's actual application in at least some jurisdictions, including

219 Cf. Avgouleas, supra note 66, at 19 (arguing that "where managerial rewards are contingent on shareholder returns, this naturally places limits on analyzing shareholders and managers as distinct stakeholder groups within banks"). I recognize that courts applying the business judgment rule usually look for conflicts of interest between managers, on the one hand, and the firm and its shareholders, on the other hand. Logically, however, if - as this Article argues-the managers should also have a duty to the public, then the notion of conflicts should be broadened to include conflicts between managers, on the one hand, and the public, on the other hand.

220 Although gross negligence is articulated as part of the business judgment rule, directors usually are not subjected to monetary damages for violating their duty of care, even when they are grossly negligent. See, e.g., Carter G. Bishop, Directorial Abdication and the Taxonomic Role of Good Faith in Delaware Corporate Law, 2007 Mich. ST. L. Rev. 905, 911; Jesse W. Markham, Jr., The Failure of Corporate Governance Standards and Antitrust Compliance, 58 S.D. L. REv. 499, 502 (2013) (observing that although it is included in the duty of care, gross negligence "has almost no place in the life of a board member of a public company because every state of the Union has enacted so-called 'exculpation' enabling laws that permit corporations to excuse their boards of any duty of care").

221 See supra subsections III.B.1, III.B.2.

222 See infra Appendix, $\$ 5$ (a) of the proposed Public Governance Duty Act, which provides this safe harbor.

223 See, e.g., Brehm v. Eisner, 746 A.2d 244, 264 (Del. 2000) (stating that due care in the corporate decisionmaking context is process due care only, not substantive due care); In re Caremark Int'l, Inc. Derivative Litig., 698 A.2d 959, 967-68 (Del. Ch. 1996) (explaining that the business judgment rule is process oriented and informed by a deep respect for all good faith board decisions). 
Delaware, that do not formally articulate a gross negligence standard as part of the rule. Delaware, for example, disallows business-judgment-rule protection for managers who act in "bad faith," 224 which is broadly defined as including conduct that "is known to constitute a violation of applicable positive law," 225 which in turn is interpreted to include a manager failing to take "steps in a good faith effort to prevent or remedy" such a violation. ${ }^{226} \mathrm{~A}$ manager's failure to use even slight care when assessing systemic harm to the public under a legally mandated public governance duty would appear to be bad faith under those interpretations.

\section{Protecting Managers Under D\&O Liability Insurance}

The final question is the extent to which managers who become subject to liability for breaching the public governance duty should be protected under D\&O liability insurance, which indemnifies managers against personal liability. Although D\&O liability insurance will be needed to incentivize good managers and also to help ensure that sufficient funds are available to properly incentivize private-action lawsuits, it might compromise the deterrent effect of imposing personal liability. ${ }^{227}$ Furthermore, because the harm resulting from systemic harm is open-ended, ${ }^{228}$ insurers may be reluctant to offer $\mathrm{D} \& \mathrm{O}$ insurance covering breaches of the public governance duty. At least one possible solution to these concerns would be to specify a limit on the amount of the claim that could be imposed for breaching the public governance duty and, like a deductible, to require managers to be personally liable for some percentage of that amount. ${ }^{229}$

The discussion above is normative, attempting to neutrally balance competing goals. Under United States law, however, regulators are technically required "to mitigate risks to the financial stability of the United States" without consideration of costs and benefits. ${ }^{230}$ That law could be interpreted to

224 See In re Walt Disney Co. Derivative Litig., 907 A.2d 693, 755 (Del. Ch. 2005) (explaining that " $[\mathrm{t}]$ he presumption of the business judgment rule creates a presumption that a director acted in good faith" and that " $[t]$ he good faith required of a corporate fiduciary includes . . . duties of care and loyalty").

225 Gagliardi v. TriFoods Int'l, Inc., 683 A.2d 1049, 1051 n.2 (Del. Ch. 1996).

226 Caremark, 698 A.2d at 971.

227 Cf. Richard MacMinn et al., Directors, Directors and Officers Insurance, and Corporate Governance, $35 \mathrm{~J}$. Ins. Issues 159, 165 (2012) (observing that "[t]he major criticism of corporate purchase of $\mathrm{D} \& \mathrm{O}$ insurance is that it creates moral hazard problems for" the managers covered by such insurance).

228 Armour \& Gordon, supra note 37, at 69 (indicating that systemic losses raise openended director liability because they "cannot readily be quantified").

229 The Appendix's proposed Public Governance Duty Act accomplishes this in $\S \S 4$ (a) and 5(b) thereof. Cf. Armour \& Gordon, supra note 37, at 69 (arguing that capping director liability by reference to income "will in most cases strike a balance between the desire to enhance deterrence while avoiding strong disincentives to director service by the most qualified").

230 Board of Governors of the Federal Reserve System, supra note 8, at 13; see supra note 64 . 
favor the first competing goal (protecting the public against systemic externalities) over the second (encouraging the best managers to serve). ${ }^{231}$

\section{Conclusion}

Although corporate risk-taking is economically necessary and even desirable, it can sometimes be harmful. There is widespread agreement that excessive corporate risk-taking was one of the primary causes of the systemic economic collapse that became the 2008-2009 financial crisis. Most financial regulation since the crisis is therefore directed at reducing excessive risk-taking by systemically important firms. That regulation usually focuses on aligning managerial and investor interests, on the assumption that investors generally would oppose excessively risky business ventures.

This Article argues that assumption is flawed. What constitutes "excessive" risk-taking depends on the observer; risk-taking is excessive from a given observer's standpoint if, on balance, it is expected to harm that observer. As a result, the law inadvertently allows systemically important firms to engage in risk-taking ventures that are expected to benefit the firm and its investors but, because much of the systemic harm from the firm's failure would be externalized onto other market participants as well as onto ordinary citizens impacted by an economic collapse, harm the public.

Pragmatically, regulators cannot control the myriad harmful externalities that result from corporate risk-taking. But excessive risk-taking that causes the failure of a systemically important firm could trigger a domino-like systemic collapse of other firms or markets, leading to widespread unemployment and poverty. ${ }^{232}$ Regulation should try to control that risk-taking. Postfinancial-crisis regulation attempts to control that risk-taking without interfering with corporate governance because financial regulation of corporate governance is thought to weaken the wealth-producing capacities of the firm. That sort of substantive financial regulation is certainly important. The Article shows, however, that it is, and inevitably will be, insufficient to control the excessive corporate risk-taking that causes systemic externalities.

The Article then examines whether regulating corporate governance could help to control that risk-taking, without unduly weakening corporate wealth-producing capacity. It concludes that managers of systemically important firms should not only have their traditional corporate governance duty to investors but also a duty-which the Article calls a "public governance duty"-not to engage in excessive risk-taking that could systemically harm the public. Such a duty would help to align private and public interests. It also would help to correct another critical regulatory failure-that substantive financial regulation usually lags financial innovation. That regulatory lag occurs because substantive financial regulation often depends on regulators

231 That law should not fully trump the first competing goal over the second because protecting the public against systemic externalities requires at least reasonably competent managers.

232 See supra note 12 and accompanying text. 
precisely understanding the particular design and structure of financial firms, markets, and other related institutions at the time the regulation is promulgated. The problem, though, is that the design and structure are constantly changing. The public governance duty, in contrast, would overcome that time lag. If the firm is proposing to engage in a risky project that represents financial innovation, its managers either have-or to fulfill their governance duties, should try to obtain-the most current information about the innovation and its consequences.

The proposed public governance duty is designed to avoid weakening corporate wealth-producing capacity. ${ }^{233}$ The duty merely requires managers of systemically important firms to price in potential systemic costs when deciding on risky projects whose failure could cause the firm to fail. This recognizes that a firm's wealth production to society should be assessed net of systemic public harm. The Article's analysis of the public governance duty also informs the larger debate over corporate governance models. The analysis shows how such a duty would fit within corporate governance legal theory. It also explains why systemic externalities should count in limiting corporate governance autonomy (and freedom of contract).

Because the public governance duty is intended to have minimal impact on existing corporate governance, this Article also examines such practical concerns as how the duty should be legally imposed, how managers should assess and balance the public costs and private benefits of a risk-taking activity, how the duty should be enforced, and to what extent managers performing the duty should have the traditional protection of a business judgment rule as a defense to liability. The last issue is especially significant because qualified managers are unlikely to want to serve without that protection.

The Appendix below proposes a Public Governance Duty Act designed to implement the goals set forth in the Article. ${ }^{234}$ Such a public governance duty should significantly reduce, but it could not completely prevent, ${ }^{235}$ the excessive risk-taking that causes systemic externalities. Even if imperfect, however, that duty should constitute an important first step $^{236}$ towards

233 Read literally, however, the Dodd-Frank Act imposes a mandate on United States regulators to reduce systemic externalities regardless of the costs of doing so. See supra notes 230-33 and accompanying text. This Article-and regulators generally-eschew such an austere and unrealistic approach.

234 In the United States, certain of those goals might be able to be implemented without the need for new legislation. See supra notes 167-70 and accompanying text (explaining that the Federal Reserve Board requires risk committees of systemically important financial firms to consider risks to the firm, not to the public; but noting $\$ 165$ (h) of the Dodd-Frank Act might already provide the Federal Reserve Board with a broad enough mandate to require those committees to also consider systemic risks to the public).

235 See, e.g., supra note 178 and accompanying text (discussing simplifying assumptions); supra notes 179-85 and accompanying text (discussing the difficulty of valuing $\$ \mathrm{Z}$, the systemic costs if the firm fails); and supra note 184 (explaining why "no estimate [of $\$ Z$ ] would be perfect").

236 There could be even weaker first steps. For example, rather than imposing a public governance "duty," government could simply legislate a public governance "right" that 
shaping corporate governance norms to begin to take the public into account. ${ }^{237}$

would permit, but not require, managers to take into account potential systemic harm. State constituency statutes sometimes take that approach. See supra note 160 and accompanying text (discussing the Pennsylvania constituency statute). Managers who then vote to favor public over investor interests would not necessarily be violating their state law corporate governance duties.

237 This Article does not directly engage the broader questions of whether corporate governance law should take into account other public interests, such as climate change and environmental harm or non-systemic economic harm, when traditional forms of regulation are insufficient. In separate articles, I use this Article's conceptual analysis as a stepping-stone to address these broader questions. I also address the possibility of designating certain managers specifically to act in the public interest in lieu of modifying the corporate governance duties of regular managers. Cf. supra note 112 (observing that an alternative to imposing a public governance duty on a firm's managers might be to designate a publicadvocate manager whose primary duty would be to represent the public, preserving the other managers' traditional duties with one exception: in any decisionmaking, the other managers would have the right to take into account the public advocate's viewpoint). 


\section{Appendix: Model Regulatory Language for} a Public Governance Duty 238

Public Governance Duty Act

SECTION 1. TITLE

(a) This Act may be cited as the "Public Governance Duty Act."

\section{SECTION 2. DEFINITIONS}

Except as otherwise specifically provided in this Act, the following definitions shall apply:

(1) The term "business judgment rule" means the legal presumption that a firm's managers should not be personally liable for harm caused by negligent decisions made in good faith and without conflicts of interest.

(2) The term "director" means a member of a systemically important firm's board of directors or such other senior manager who shares or otherwise has ultimate responsibility to manage the firm.

(3) The term "fail" means that a firm admits in writing its inability to pay its debts; or makes a general assignment for the benefit of creditors; or becomes subject to a bankruptcy, insolvency, winding-up, liquidation, or other similar case or proceeding; or otherwise ceases normal business operations due to financial distress.

(4) The term "public governance duty" has the meaning set forth in Section 3(a) of this Act.

(5) The term "systemically important firm" means a firm that has been designated as systemically important by [name of applicable governmental body that is authorized to make that designation].

\section{SECTION 3. PUBLIC GOVERNANCE DUTY}

(a) THE PUBLIC GOVERNANCE DUTY. In addition to the duties a director may have to shareholders or other stakeholders, each director of a systemically important firm has a duty ("public governance duty") not to engage the firm in risk-taking that, viewed at the time of such risk-taking and either itself or in combination with other factors of which such director is or should be aware, could reasonably cause the firm to fail ${ }^{239}$ unless such director (1) first performs one of the processes set forth in subsection (b) of this

238 For an analysis of the process by which this proposed Public Governance Duty Act or alternative language stating a public governance duty could be implemented into law, see supra notes 159-70 and accompanying text.

239 Cf. supra notes 178, 187-88 and accompanying text (discussing the risk-taking for which managers should assess the public governance duty). Directors making this determination would be protected by the business judgment rule. 
Section and (2) based thereon, determines that the firm should engage in that risk-taking.

(b) PROCESS. For each risk-taking described in subsection (a) of this Section, a director shall perform the process described in either subsection (b) (1) or subsection (b) (2) of this Section.

(1) The director shall assess and balance the benefits and costs of such risk-taking, including potential systemic harm to the public, in the manner such director would lawfully assess and balance any other relevant benefits and costs when making a corporate governance decision; ${ }^{240}$

(2) The director shall assess and balance the benefits and costs of such risk-taking, including potential systemic harm to the public, according to the following methodology: [the Act could insert here, for example, methodology extracted from this Article's text]. ${ }^{241}$

\section{SECTION 4. LIABILITY AND ENFORCEMENT}

(a) LIABILITY. A director who violates the public governance duty shall be liable for up to $[\$ 250,000]^{242}$ per risk-taking.

(b) PUBLIC ENFORCEMENT. [Name of applicable governmental agency that is authorized to enforce this Act] (the "Agency") may enforce this Act by [insert appropriate administrative and/or judicial legal actions that may be taken to impose liability or to restrain a risk-taking for which a director has violated the public governance duty]. ${ }^{243}$

(c) PRIVATE ENFORCEMENT. A person may bring a civil action to enforce this Act on behalf of and in the name of the Agency. ${ }^{244}$

(1) A copy of the complaint and written disclosure of substantially all material evidence and information the person possesses shall be served on the Agency. The complaint shall be filed in camera, shall remain under seal, and shall not be served on the defendant until the Agency elects whether to intervene and proceed with the action.

(2) The Agency shall elect whether to intervene and proceed with the action within sixty days after it receives both the complaint and the material evidence and information referenced in subsection (c) (1) of this Section. Before the expiration of that sixty-day period, the Agency shall (A) proceed with the action, in which case the action shall be conducted by the Agency, or (B) notify the court that it declines to take over the action, in which case the person initiating the action shall have the right to conduct the action.

240 See supra notes 170-72 and accompanying text.

241 See supra text accompanying notes 171-99.

242 This number is merely suggested. Compare text accompanying supra notes 201-03 (discussing how to incentivize qui tam actions) with section 5(b) of the Public Governance Duty Act (limiting director insurance coverage).

243 See supra notes 196-99 and accompanying text.

244 See supra notes 201-05 and accompanying text (discussing qui tam actions). 
(3) If the Agency proceeds with the action, it shall have full responsibility for prosecuting the action, and shall not be bound by any act of the person bringing the action. Such person, however, shall receive at least [fifteen percent but not more than thirty percent] ${ }^{245}$ of the proceeds of the action or settlement thereof, depending upon the extent to which the Agency determines such person substantially contributed to the prosecution of the action.

(4) If the initiating person conducts the action because the Agency declined to take it over, such person shall have the right to the proceeds of the action or settlement thereof. ${ }^{246}$ However, if the action is dismissed or the defendant otherwise prevails, the court may require such person to pay the defendant's reasonable attorneys' fees and expenses if the court finds that the action was clearly frivolous, clearly vexatious, or brought primarily for purposes of harassment.

\section{SECTION 5. DEFENSES AND INSURANCE}

(a) DEFENSES. This Act shall not restrict the availability of the business judgment rule as a defense to liability, provided a director claiming that defense either (A) uses at least slight care when performing the public governance duty or (B) in good faith performs the process set forth in subsection 3(b) (2) of this Act. ${ }^{247}$

(b) INSURANCE. A director who violates the public governance duty shall be personally liable for at least [ten ${ }^{248}$ percent of any liability award or settlement against such director. Such personal liability may not be reimbursed, indemnified, or otherwise directly or indirectly paid or hedged by insurance (including directors and officers liability insurance) or any other means. ${ }^{249}$

\section{SECTION 6. WHISTLEBLOWING RIGHTS AND OBLIGATIONS}

(a) Each employee of a systemically important firm shall have the right, and each director of such a firm shall have the obligation, to report to the Agency any violation or potential violation of the public governance duty of which such employee or director has knowledge and to assist the Agency in an investigation of such violation. ${ }^{250}$

\footnotetext{
245 Cf. supra text accompanying note 203 (discussing citizen-plaintiff recovery in qui tam actions).

246 See id.

247 See supra notes 206-26 and accompanying text (discussing the requirement to use at least slight care as part of a business judgment rule defense).

248 This number is merely suggested. Compare text accompanying supra note 229 (discussing how much personal liability is needed to discourage violations of the public governance duty), with section 4(a) of the Public Governance Duty Act.

249 See supra notes 227-29 and accompanying text (discussing D\&O insurance).

250 See supra notes 197-200 and accompanying text (discussing whistleblowing).
} 
(b) An employee or director who acts in accordance with subsection (a) of this Section, (1) shall not, on account of such action, be liable to any person under any law, rule, or regulation or under any contract or other agreement, and (2) may not, on account of such action, be discharged, demoted, suspended, threatened, or harassed, directly or indirectly, or in any other manner discriminated against, by such employee's or director's firm or by any other person. ${ }^{251}$

(c) If the Agency finds, after notice and a hearing, that a director has willfully violated such director's obligation under subsection (a) of this Section, it may impose a civil penalty against such director of up to $[\$ 20,000] .{ }^{252}$

251 Section 4(b) of the Public Governance Duty Act might also offer monetary incentives to non-director employee whistleblowers, such as allowed under 15 U.S.C. $\$ 78 u-6$ (b) (2012) in a different context.

252 This number is merely suggested. 